\title{
Comparative Analysis of Worker Reproduction and Policing in Eusocial Hymenoptera Supports Relatedness Theory
}

\author{
Tom Wenseleers ${ }^{1,2, *}$ and Francis L. W. Ratnieks ${ }^{1,2, \dagger}$
}

1. Institute for Advanced Study, Wallotstrasse 19, 14193 Berlin, Germany;

2. Laboratory of Apiculture and Social Insects, Department of Animal and Plant Sciences, University of Sheffield, Sheffield S10 2TN, United Kingdom

Submitted January 3, 2006; Accepted June 7, 2006; Electronically published October 18, 2006
A BSTRACT: In many bees, wasps, and ants, workers police each other in order to prevent individual workers from selfishly producing their own male offspring. Although several factors can selectively favor worker policing, genetic relatedness is considered to be of special importance. In particular, kin selection theory predicts that worker policing should be more common in species where workers are more related to the queen's sons than to other workers' sons. Here we provide strong novel support for this theory based on a comparative analysis of policing and male parentage in 109 species of ants, bees, and wasps. First, an analysis of behavioral data confirms that worker policing occurs more frequently in species where workers are more related to the queen's sons than to other workers' sons. Second, an analysis of male parentage shows that a significantly higher percentage of the males are workers' sons in species where the workers are more related to other workers' sons. Both conclusions also hold if data are analyzed using phylogenetically independent contrasts. Although our analysis provides strong overall support for the theory that relatedness affects kin conflict over male parentage, there is also significant residual variation. Several factors that may explain this variation are discussed.

Keywords: worker policing, queen policing, worker reproduction, social Hymenoptera, inclusive fitness, kin selection.

A major challenge in evolutionary biology is to explain how social groups can reduce or prevent costly conflicts

* Present address: Laboratory of Entomology, Zoological Institute, Catholic University of Leuven, Naamsestraat 59, 3000 Leuven, Belgium; e-mail: tom.wenseleers@bio.kuleuven.be.

† E-mail: f.ratnieks@sheffield.ac.uk.

Am. Nat. 2006. Vol. 168, pp. E163-E179. (C) 2006 by The University of Chicago. 0003-0147/2006/16806-41539\$15.00. All rights reserved. among group members (Frank 1995, 2003). The problem is an important one and applies across all levels of biological organization, from conflicts in the genome to conflicts in societies or among partners in multispecies mutualisms (Keller 1999; Hammerstein 2003; Foster and Wenseleers 2006; Ratnieks et al. 2006). In social groups, where all individuals are affected to a greater or lesser extent by the behavior of others, conflict is usually detrimental because individuals serving their own selfish interests reduce group productivity (Hardin 1968; Frank 1995; Wenseleers and Ratnieks 2004). Nevertheless, conflict-induced social collapse is not inevitable because conflicts are frequently well resolved (Keller 1999; Ratnieks et al. 2006).

One mechanism that can help to resolve conflict is social policing, whereby group members mutually suppress each other's selfish actions (Leigh 1977; Ratnieks 1988; Ratnieks and Visscher 1989; Frank 1995, 2003). Some of the clearest and best-understood examples of mutual policing occur in insect societies, where policing acts in several contexts (Ratnieks 1988; Monnin and Ratnieks 2001; Wenseleers et al. 2003; Ratnieks and Wenseleers 2005; Ratnieks et al. 2006). One context is the policing of worker reproduction (Ratnieks 1988; Ratnieks and Visscher 1989). In most ants, bees, and wasps, individual workers can exploit the colony by laying unfertilized eggs that develop into males if reared (Bourke 1988b; Ratnieks et al. 2006). However, in many species, workers kill or "police" other workers' eggs before they can hatch (reviewed in Wenseleers et al. 2004b; Ratnieks and Wenseleers 2005; Ratnieks et al. 2006). In some species, workers even aggress nestmates with active ovaries, which can result in the victim being killed or cause it to regress its ovaries (Visscher and Dukas 1995; Monnin and Ratnieks 2001; Hartmann et al. 2003; Iwanishi et al. 2003; Ratnieks et al. 2006). The result of this policing behavior is that the reproductive division of labor is reinforced, with more of the colony's males being the queen's sons.

What circumstances select for worker policing? One favored theory is that worker policing is a classic case of a kin-selected trait (Hamilton 1964) that is favored if the workers are on average more closely related to the queen's 
sons than to other workers' sons (Ratnieks 1988; also see Starr 1984; Woyciechowski and Lomnicki 1987). In this situation, policing workers benefit from eliminating other workers' sons because this allows the queen's sons to be reared instead. Workers are more related to the queen's sons if the colony is headed by one or more multiplemated queens (Ratnieks 1988) or by several single-mated but related mother queens (Crozier and Pamilo 1996). Initial data were consistent with this hypothesis. Male production by workers was found to be more prevalent in bumblebees and stingless bees, which typically have singlemated queens, than in honeybees and Vespula wasps, which typically have multiple-mated queens (Ratnieks 1988). In addition, worker policing via egg eating was discovered in three species of Apis honeybees (Ratnieks and Visscher 1989; Halling et al. 2001; Oldroyd et al. 2001) and in the common wasp Vespula vulgaris (Foster and Ratnieks 2001a), which all have multiple-mated queens (Palmer and Oldroyd 2000; Foster and Ratnieks 2001a). Finally, in the yellow jacket wasp Dolichovespula saxonica, genetic analysis indicated that worker policing occurs in colonies headed by a multiple-mated but not a singlemated queen (Foster and Ratnieks 2000).

More recent data, however, show that worker policing also occurs in species where queen mating frequency is below 2, for example, in the ant Camponotus floridanus (Endler et al. 2004) and the hornet Vespa crabro (Foster et al. 2002), or in species that reproduce parthenogenetically, such as the ant Platythyrea punctata (Hartmann et al. 2003) and the Cape honeybee Apis mellifera capensis (Pirk et al. 2003; see table A1). This has led to doubts concerning the importance of relatedness in selecting for worker policing (Foster et al. 2002; Hartmann et al. 2003; Pirk et al. 2003, 2004; Endler et al. 2004; Gadagkar 2004; Wilson 2005). This doubt was reinforced by Hammond and Keller (2004), who used a comparative analysis of 50 species of ants, bees, and wasps to show that the proportion of males that are workers' sons is not influenced by relatedness.

Given these somewhat mixed results, what role does relatedness play in selecting for worker policing and determining male parentage in social insects? In this article, we will address this question in two ways. First, we provide a detailed analysis of behavioral studies of worker reproduction and policing in 48 species of ants, bees, and wasps. This analysis confirms that worker policing does occur more frequently in species where workers are more related to the sons of the queen than in species where they are more or equally related to the offspring of other workers. Second, we perform a more extensive analysis of male parentage than that presented by Hammond and Keller (2004) by using 90 species and show that, as predicted, significantly more of the males are workers' sons in species where the workers are more related to other workers' sons than in species where they are more related to the queen's sons. Both conclusions also hold when data are analyzed in a phylogenetic context. Although our analyses provide strong overall support for the theory that relatedness affects kin conflict over male parentage, there is also significant unexplained variation. Some of the factors that may cause this residual variation are discussed.

\section{Methods}

\section{Relatedness Estimates}

In all analyses, we used the difference in the relatedness of workers to workers' versus queen's sons $\left(r_{\text {diff }}=\right.$ $\left.r_{\mathrm{w}-\mathrm{wm}}-r_{\mathrm{w}-\mathrm{qm}}\right)$ as the predictor variable. Our expectation was that in species where workers are more related to the queen's sons $\left(r_{\text {diff }}<0\right),(1)$ worker policing should be more common and (2) the percentage of males that are workers' sons should be lower compared with species where workers are more related to other workers' sons ( $r_{\text {diff }}>0$; Ratnieks 1988). For species with colonies headed by a single queen (monogyny) and where variation in colony kin structure is caused by variation in the effective mating frequency of queens, we used the formula $r_{\text {diff }}=\left(2 r_{w-w}-1\right) / 4$, where $r_{\mathrm{w}-\mathrm{w}}$ is the relatedness among adult workers (Hammond and Keller 2004). For species with variation in queen number (polygyny), predictions about worker reproduction are more complicated because both queen number and queenqueen relatedness are important. For these species we estimated $r_{\text {diff }}$ from the actual relatedness of workers to queens $\left(r_{\mathrm{w}-\mathrm{q}}\right)$ and among workers $\left(r_{\mathrm{w}-\mathrm{w}}\right)$ as $r_{\text {diff }}=$ $\left(r_{\mathrm{w}-\mathrm{w}}-r_{\mathrm{w}-\mathrm{q}}\right) / 2$ (Hammond and Keller 2004) or directly from the formulas $r_{\mathrm{w}-\mathrm{wm}}=(2+k) /\left(8 k N_{\mathrm{e}}\right)$ and $r_{\mathrm{w}-\mathrm{qm}}=$ $\left[1+G\left(N_{\mathrm{e}}-1\right)\right] / 4 N_{\mathrm{e}}$, where $k$ is the effective queen mating frequency, $N_{\mathrm{e}}$ is the effective number of queens, and $G$ is the relatedness among them (Pamilo 1991). Unless otherwise noted, relatedness values were all estimated using genetic markers. In two species, Platythyrea punctata and Apis mellifera capensis, workers are known to produce diploid female offspring through thelytokous parthenogenesis (table A1). For those species, we set $r_{\text {diff }}=0$ because the relatedness to the female offspring of other workers is the same as the relatedness to sisters. In our comparative analyses, we used $r_{\text {diff }}$ either as a continuous variable or we coded $r_{\text {diff }}$ dichotomously as 1 if $r_{\text {diff }}>0$ and as 0 if $r_{\text {diff }}<0$. A value of 0.5 was used if $r_{\text {diff }}$ was 0 or not significantly different from 0 (as demonstrated by tests reported in the original studies). The latter allowed for the fact that if $r_{\text {diff }}$ is 0 , worker policing is selectively neutral and on an a priori basis is equally likely to be present or absent on relatedness grounds.

We did not include colony size as a predictor variable 
in any of the analyses because reliable estimates were lacking for many species and because theory shows that it does not have much effect on the expected level of worker reproduction (Wenseleers et al. 2004b).

\section{Analysis 1: The Incidence of Worker Policing}

As a first test of the relatedness hypothesis for the evolution of worker policing, we compared the frequency with which worker policing is observed in species of eusocial Hymenoptera, where workers are either more related to other worker's sons $\left(r_{\text {diff }}>0\right)$ or more related to the queen's sons $\left(r_{\text {diff }}<0\right)$. Observations of nonreproductive workers eating worker-laid eggs or aggressing reproductive workers were taken as evidence for worker policing. If egg eating by workers did not result in the differential removal of worker-laid eggs or if aggression was not specifically targeted at reproductive workers, then this was not considered worker policing. In addition, if egg eating and aggression only occurred among egg-laying workers, then this was considered worker-dominance behavior rather than worker policing, that is, reflecting worker-worker competition for egg-laying rights. Finally, we also scored the occurrence of queen policing, that is, cases where the mother queen kills worker-laid eggs or aggresses egg-laying workers. In inclusive fitness terms, queen policing is readily selected for because a queen is always more related to sons (0.5) than to workers' sons (grandsons, 0.25 ; Trivers and Hare 1976). Nevertheless, queen policing might be expected to have less benefit in species where the workers already police. Therefore, we also tested for a negative association between the occurrence of queen and worker policing. Species where queen or worker policing have clearly been shown to be absent were also included, provided that the fate or survival of worker-laid eggs had been reliably measured in queenright colonies.

After an extensive literature search, and following these criteria, we found data on 48 species. For 39 of these, good relatedness estimates were available based on genetic studies or from their mating biology (table A1). For another nine, they could be inferred with high confidence based on comparison with closely related species (table A1). Data on policing in another 14 species were also available but could not be included because good relatedness estimates were lacking. Details on the actual evidence used to infer presence or absence of policing for each species are given in the notes to table A1.

\section{Analysis 2: Male Parentage}

As a second test of the relatedness hypothesis for the evolution of worker policing, we compared the percentage of worker-produced adult males in queenright colonies
(WPM) in species where workers are either more related to other workers' sons $\left(r_{\text {diff }}>0\right)$ or more related to the queen's sons $\left(r_{\text {diff }}<0\right)$. An exhaustive literature search revealed data on male parentage in 90 species of eusocial Hymenoptera. Estimates for 50 species were largely based on Hammond and Keller (2004), which focused on studies using microsatellite markers. In addition, we included recently published microsatellite-based studies of 13 species, plus studies that used other genetic markers: allozymes ( 24 species), DNA fingerprinting (one species), and heritable body-color markers (three species; table A2). Finally, we also included data based on direct behavioral observation for four species. Species where workers lack functional ovaries and are therefore fully sterile were excluded. All genetic studies used estimates of WPM that took into account the power of the genetic markers to detect workers' sons using either exclusion (Foster et al. 2001) or maximum likelihood approaches (e.g., Contel and Kerr 1976; Owen and Plowright 1982; Hastings et al. 1998; Tóth et al. 2002b). Behavioral studies were retained only when they gave reliable information on the percentage of eggs that were worker laid and the probability of worker-laid eggs being reared into adulthood. If an estimate of WPM was given in the original behavioral study, this was used; otherwise, it was calculated as WPM $=p \times s_{w} /\left[p \times s_{w}+\right.$ $(1-p) \times m \times s_{q}$ ], where $p$ is the percentage of eggs that are worker laid, $s_{w}$ and $s_{q}$ are the proportions of the workers' and the queen's eggs that are reared to adulthood, and $m$ is the proportion of the queen's eggs that are male, which was assumed to be $1 / 2$. The latter was conservative, given that the queen usually lays a majority of female worker-destined eggs. If multiple estimates of WPM were available for a single species, then these were combined into a single estimate by calculating the estimated total number of workers' sons out of a given total number of males whose maternity could be assigned; relatedness estimates were averaged using the number of colonies analyzed as weights. All data on WPM were from queenright colonies. For three species, the halictid bee Augochlorella striata and the ants Rhytidoponera chalybaea and Rhytidoponera confusa, colonies can either be headed by a primary queen or, when she dies, by mated workers. However, because colonies headed by mated workers undergo a brief period of queenlessness, such colonies were not included in the estimate of WPM. Technical details on the estimation of WPM for particular species are given in the notes to table A2.

Hammond and Keller (2004) excluded studies not using microsatellites, arguing that they were unreliable. However, the data in table A2 show that this is not the case. The mean number of males whose maternity could be assigned is in fact significantly larger for studies using body-color markers (mean $n_{\mathrm{a}}=10,156.3, n=3$ ) than for 
those using microsatellites (mean $n_{\mathrm{a}}=146.9, n=67$, $t=6.05, P<1.10^{-10}$ ) and is nonsignificantly different between microsatellite-based and allozyme-based studies (mean $n_{\mathrm{a}}=146.3, n=24, t=0.01, P=.99$ ) or between microsatellite-based and behavioral studies (mean $n_{\mathrm{a}}=$ 270.9, $n=4, t=1.18, P=.24$ ). In addition, multiple estimates for the same species obtained using different techniques or markers generally showed good agreement (table A2). However, it is true that irrespective of the technique being used, the quality of the studies varied. While some studies analyzed very many males, approximately $40 \%$ of the microsatellite-based studies (27/67) and 33\% of the allozyme-based studies $(8 / 24)$ had $<50$ assignable males. In these cases, the absence of worker reproduction could easily be due to low sample size. Therefore, as a means of data quality control, we also carried out all analyses by excluding species for which (1) $n_{\mathrm{a}}<50$ and no worker reproduction was detected, and (2) $n_{\mathrm{a}}<50$ irrespective of whether worker reproduction was detected or not. Excluding small studies also avoided a potential bias in the analysis, because small studies were significantly more common in species where workers were more related to other workers' sons and hence where worker-produced males would have been expected $\left(n_{\mathrm{a}}\right.$ was $<50$ in $32 / 75=43 \%$ of the species with $r_{\text {diff }}>0$ but only in $1 / 15=7 \%$ of the species with $r_{\text {diff }}<0$; Fisher's exact test, $P=.008)$.

\section{Intraspecific Variation}

For some species, there was significant intercolony variation in both colony kin structure and the percentage of males that were workers' sons (table A2). For example, in the saxon wasp Dolichovespula saxonica, the percentage of males that are workers' sons decreases with increasing queen paternity (Foster and Ratnieks 2000). To take into account the possibility of conditional policing behavior, we also carried out analyses of male parentage incorporating intraspecific variation. Two separate analyses were performed, either incorporating all intraspecific variation or including intraspecific variation only if there were statistically significant differences in the maternal origin of males between colony classes (e.g., nests with single-mated vs. multiple-mated queens). The latter seemed appropriate given that otherwise, any differences in male parentage between colony classes were not statistically supported and that there was no reason to suppose that policing behavior was expressed conditionally as a function of the colony kin structure. The significance in the variation of male parentage between colony classes was based either on published $P$ values (based on Spearman's rank correlations between per colony estimates of WPM and worker-worker relatedness), or, if these were unavailable, on Fisher's exact tests to compare the number of workers' sons out of a given total number of assignable males in the two colony classes.

\section{Phylogenetically Controlled Comparative Analyses}

To analyze the data in a phylogenetic context, we used a version of Grafen's Phylogenetically Independent Contrasts (PICs; Grafen 1989). The difference in relatedness between workers' sons and queen's sons $\left(r_{\text {diff }}\right)$, either continuously or dichotomously coded, was used as the predictor variable. The dependent variable was the presence or absence of worker policing (analysis 1) or the $\log _{10}(y+1)$ transformed percentage of worker-derived males (WPM; analysis 2). The PICs were calculated using the PDTREE module (Purvis and Garland 1993; Garland et al. 1999; Garland and Ives 2000; Midford et al. 2003) of the Mesquite package (Maddison and Maddison 2004). This program calculates PICs following Grafen (1989). In their simplest forms, phylogenetic generalized least squares models (GLS; e.g., Grafen 1989; Martins and Hansen 1997) are mathematically and statistically equivalent to Felsenstein's (1985) method. The GLS methods, however, are more flexible, as they allow for the use of both continuous and dichotomous variables, provided that the residuals are normally distributed (Grafen 1989; Garland et al. 1993; Grafen and Ridley 1996) and that the underlying evolutionary process is interpreted following Grafen (1989). Under Grafen's view of evolution, the response to selection is immediate. This is different from Felsenstein's (1985) view, which assumes that evolution proceeds by random genetic drift or in response to fluctuating directional selection. Statistical significance was assessed using regression through the origin. Because we had clear a priori hypotheses, we used one-sided tests. Polytomies in the phylogeny were taken into account by reducing the number of degrees of freedom of the statistical tests (Purvis and Garland 1993). Both raw data analyses and independent contrasts can occasionally give wrong answers under

Figure 1: Composite phylogeny used in comparative analyses. $a$, Phylogeny used in the comparative analysis of worker policing. $b$, Phylogeny used in the comparative analysis of male parentage. In $b$, within-species variation is shown for one species, Dolichovespula saxonica, where there were significant differences in the proportions of males that are workers' sons in low-paternity versus high-paternity colonies (table A2). Branches shown in red, red-dotted, and black lines are cases were $r_{\text {diff }}<0, r_{\text {diff }}=0$, and $r_{\text {diff }}>0$, respectively. When $r_{\text {diff }}<0$, that is, when workers are more related to queen's sons than to other workers' sons, worker policing is most strongly favored. 

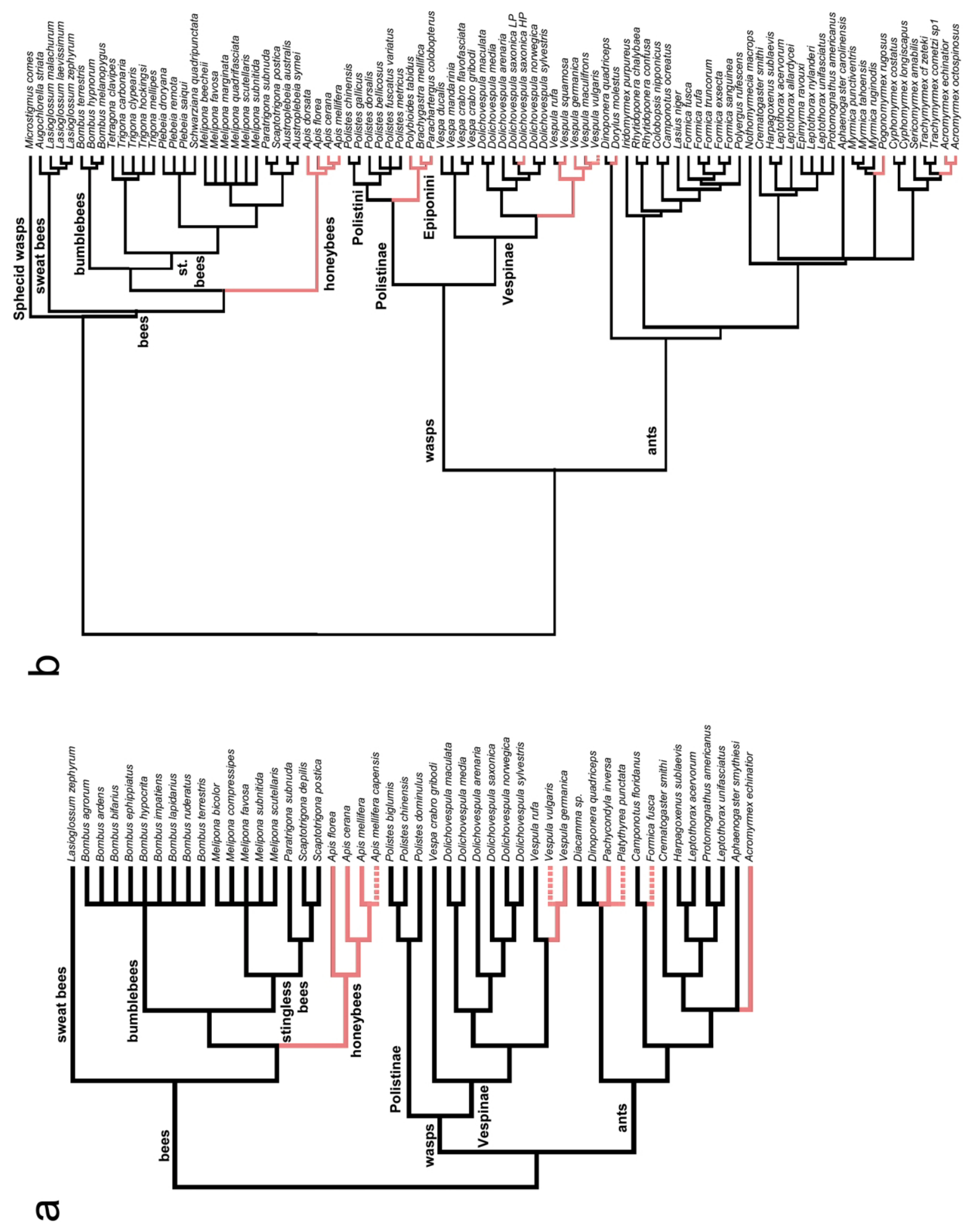
some evolutionary scenarios, and more recent methods (e.g., PMM; Housworth et al. 2004) may be a better choice when more is known about the underlying evolutionary processes. Instead of applying these other methods, here we follow the suggestion of Martins et al. (2002) of placing confidence only in conclusions that hold true for both independent contrasts and raw data analyses.

To calculate independent contrasts, we constructed two phylogenies that included all the species present in analyses 1 and 2 (fig. 1). These phylogenies followed the one in Hammond and Keller (2004) with the following changes. Sweat bees were added as basal to the long-tongued bees (Alexander and Michener 1995). For honeybees, leafcutter ants, and bumblebees, the molecular phylogenies of Arias and Sheppard (2005), Villesen et al. (2002), and Kawakita et al. (2004) were used. Relationships among the Polistinae wasps followed the combined morphological and molecular phylogeny of Arévalo et al. (2004). Relationships among Vespinae wasps followed the morphological phylogeny of Carpenter and Perera (2006). Ant subfamily relationships followed the morphological phylogeny of Baroni Urbani et al. (1992). The genus Rhytidoponera, belonging to the newly recognized subfamily of the Ectatomminae, was added as basal to the Formicinae, as indicated by recent molecular phylogenies (e.g., Saux et al. 2004). Finally, phylogenetic relationships among formicoxenine ants followed the molecular phylogeny of Beibl et al. (2005). Branch lengths were set following Grafen (1989), whereby species at the tips of the phylogeny are contemporaneous and the depth of each node is set equal to one less than the number of tip species that descend from it (Grafen 1989). This branch length method performed well, as judged by the branch length statistic of Garland et al. (1992). Results, however, were robust with respect to various other suggested branch length transformations (e.g., that of Pagel 1992). In addition, changing some phylogenetic relationships did not change any of the conclusions. For example, considering honeybees rather than bumblebees as the sister group of the stingless bees, as indicated by morphology-based phylogenies (Engel 2001; Schultz et al. 2001) but not most DNA-based phylogenies (Cameron and Mardulyn 2001, but see Ascher et al. 2001; Thompson and Oldroyd 2004), led to the same overall conclusions. Similarly, using another phylogeny of polistine wasps (Pickett and Wenzel 2004) or using alternative topologies for ant subfamily relationships did not affect any of the conclusions.

\section{Effect Sizes}

To investigate what percentage of the variance was explained by relatedness in our data set, we calculated the squared correlation $\left(r^{2}\right)$ between whether or not worker policing was expected based on $r_{\text {diff }}$ and (1) whether worker policing was actually observed (analysis 1), and (2) whether or not WPM reached very low levels (WPM $\leq$ $2 \%$ ), as expected if most worker reproduction is policed (analysis 2). Expected levels of worker policing were scored as 0 or 1 for $r_{\text {diff }}>0$ and $<1$, or as 0.5 if $r_{\text {diff }}$ was not significantly different from 0 . As a measure of the effect size in the phylogenetically controlled analyses, we calculated the observed slope in the phylogenetic regression divided by the expected slope if data perfectly followed the theory (Hammond and Keller 2004). In the analysis of male parentage, we used two values for the expected level of worker reproduction when $r_{\text {diff }}$ was $>0$ : a relatively moderate one, $10 \%$, and a more extreme one, $100 \%$. The first value, $10 \%$, is typical for genera such as Dolichovespula, which have widespread worker reproduction and no worker policing but also quite effective queen policing (Foster et al. 2001; Wenseleers et al. 2005a, 2005b; Wenseleers and Ratnieks 2006; T. Wenseleers, A. Tofilski, F. S. Nascimento, and F. L. W. Ratnieks, unpublished manuscript). On the other hand, the extreme value of $100 \%$ might be expected if worker reproduction was not policed by either the queen or workers and also had no colonylevel costs (Wenseleers et al. 2004b). For $r_{\text {diff }}<0$, the expected level of worker reproduction was set to 0 , and for $r_{\text {diff }}$ not significantly different from 0 , it was set at an intermediate value (i.e., $5 \%$ or $50 \%$, respectively). As in the comparative analysis of male parentage, the expected values were $\log _{10}(y+1)$ transformed. Following Hammond and Keller (2004), we considered effect sizes of $>70 \%$ as large, $30 \%-70 \%$ as moderate, and $<30 \%$ as small.

\section{Results \\ Analysis of the Incidence of Worker Policing}

Raw Data. Worker policing has been observed in 14 species of ants, bees, and wasps with known colony kin structure. Out of these, it occurs via egg eating in 10 species, egg eating and aggression in two species, and aggression only in another two species (table A1). As predicted, worker policing is significantly more common in species where $r_{\text {diff }}<0$ (WP present in 7/7 species, in three honeybees: Apis cerana, Apis florea, and Apis mellifera; one yellow jacket: Vespula germanica; and three ants: Acromyrmex echinatior, Formica fusca, and Pachycondyla inversa) than in species where $r_{\text {diff }} \geq 0$ (WP present in only $7 / 34=21 \%$ of the species; table A1, Fisher's exact test, $P=.00015)$. The typical absence of worker policing in species where workers are more related to other workers' sons is striking, and although rarely discussed, is actually well supported. For example, in the single-mated ant $\mathrm{Di}$ noponera quadriceps, worker-laid eggs are never eaten by 
subordinate workers, but many are killed by the mated worker that heads the colonies of this species (Monnin and Peeters 1997). In another monogynous and monandrous ant, Leptothorax unifasciatus, experiments have shown that worker-laid eggs introduced into queenright colonies are not differentially policed (N. Stroeymeyt, E. Brunner, and J. Heinze, personal communication). Similarly, in the exclusively single-mated stingless bees, workers normally do not eat eggs laid by other workers (Tóth et al. 2004; Velthuis et al. 2005), and in one species where they do, in Melipona bicolor, it is associated with direct competition among egg-laying workers (Velthuis et al. 2002; Koedam et al. 2007) and thus represents workerdominance behavior rather than worker policing. Finally, the predominantly single-mated wasp genera Dolichovespula and Polistes and the low-paternity yellow jacket Vespula rufa all have queen policing and mutual egg eating by reproductive workers but not true worker policing (Saigo and Tsuchida 2004; Ratnieks et al. 2006; T. Wenseleers, A. Tofilski, F. S. Nascimento, and F. L. Ratnieks, unpublished manuscript; table A1). The only exception may be Dolichovespula saxonica, where worker policing is thought to occur in multiple paternity colonies (Foster and Ratnieks 2000). However, this remains to be confirmed by direct observation.

Of the seven species with worker policing and with $r_{\text {diff }} \geq 0$, two species have $r_{\text {diff }}=0$ (the two thelytokous species, Apis mellifera capensis and Platythyrea punctata) and one, Vespula vulgaris, has a value for $r_{\text {diff }}$ that is not significantly different from $0(0.005$, lower $95 \%$ confidence limit: $r_{\text {diff }}=-0.015$; Foster and Ratnieks 2001a). In these three species, worker policing is neither selected for nor against, and particularly for A. mellifera capensis and $V$. vulgaris, it would in fact be expected to be present given that ancestrally, worker policing was almost certainly present. For A. mellifera capensis, there is also some evidence that worker policing is less effective compared with Apis mellifera mellifera (Pirk et al. 2003) and may even be absent in some colonies (Moritz et al. 1999; Beekman et al. 2002). On the other hand, for the four remaining species (the three ants Aphaenogaster smythiesi, Camponotus floridanus, and Diacamma sp. and the hornet Vespa crabro), it is clear that factors other than relatedness must have selected for worker policing (see discussion). Overall, relatedness explained 55\% of the variation in the observed incidence of worker policing, as judged by the correlation between the observed and expected incidence based on $r_{\text {diff }}$ (see "Methods"; Pearson $r=0.74, n=41, P=.00000002$ ).

Queen policing $(\mathrm{QP})$ is also widespread, being present in 30 species of ants, bees, and wasps with known colony kin structure (table A1). Of these, it occurs via egg eating in 13 species, egg eating and aggression in 14 species, and aggression only in three species. In contrast to worker policing, queen policing is more common in species with $r_{\text {diff }} \geq 0$ (in 30/34 species; table A1) than in species with $r_{\text {diff }}<0$ (in 0/4 species; Fisher's exact test, $P=.0009$ ). In addition, there is a negative association between the occurrence of queen and worker policing, with queen policing being significantly rarer in species that have worker policing (QP present in only 2/9 species) than in species that do not (QP present in 22/23 species; Fisher's exact test, $P=.00009)$. These correlations are expected given that there is less benefit for the queen to police if workers also police each other and that worker policing occurs predominantly in species where $r_{\text {diff }}<0$.

All the above conclusions also hold if the nine species for which relatedness was inferred indirectly through comparison with closely related species are excluded (table A1; association between $r_{\text {diff }}$ and worker policing: $P=.0005$; association between $r_{\text {diff }}$ and queen policing: $P=.002$; negative association between queen and worker policing: $P=.0002)$.

Comparative Analysis. The above conclusions are supported by analyses of phylogenetically independent contrasts. Across the phylogeny (fig. 1a), decreases in the relatedness to workers' versus queen's sons $\left(r_{\text {diff }}\right)$ are associated with a significant increase in the incidence of worker policing (fig. 2a). Significance levels range from .0003 to .01 , depending on whether $r_{\text {diff }}$ is continuously or dichotomously coded and whether or not studies with indirect relatedness estimates are excluded (table 1, pt. A). Key contrasts that contribute to the significance of this result are (1) Apis honeybees versus bumblebees and stingless bees (contrast $\mathrm{C} 1$ in fig. 2a); (2) Vespula versus Dolichovespula (C2); (3) V. germanica and V. vulgaris versus V. rufa (C3); (4) P. inversa versus other Ponerine ants (C4); (5) A. echinatior versus other Myrmicines (C5); and (6) Diacamma, Pachycondyla, and Platythyrea versus D. quadriceps (C6). In each of these contrasts, the former group in the pair has a lower $r_{\text {diff }}$ and has worker policing. Two contrasts that did not follow the relatedness prediction were (1) Vespa crabro versus Vespula and Dolichovespula (contrast NC1 in fig. 2a) and (2) A. mellifera capensis versus A. mellifera mellifera/ligustica (NC2). In these cases, the former species in the pair had a higher $r_{\text {diff }}$ but still had worker policing. Overall, however, relatedness had a reasonable predictive power, with effect sizes being moderately large ( $43 \%-51 \%$; table $1, \mathrm{pt}$. A).

Two conclusions that are also supported by independent contrasts are that increases in $r_{\text {diff }}$ are associated with an increased incidence of queen policing (all species included, $r_{\text {diff }}$ continuously coded: $\beta=2.93$, adjusted $\mathrm{df}=25$, $t=2.00, P=.03 ; r_{\text {diff }}$ dichotomously coded: $\beta=0.87$, adjusted $\mathrm{df}=25, t=4.44, P=.00008)$ and that an increased incidence of worker policing correlates with a de- 

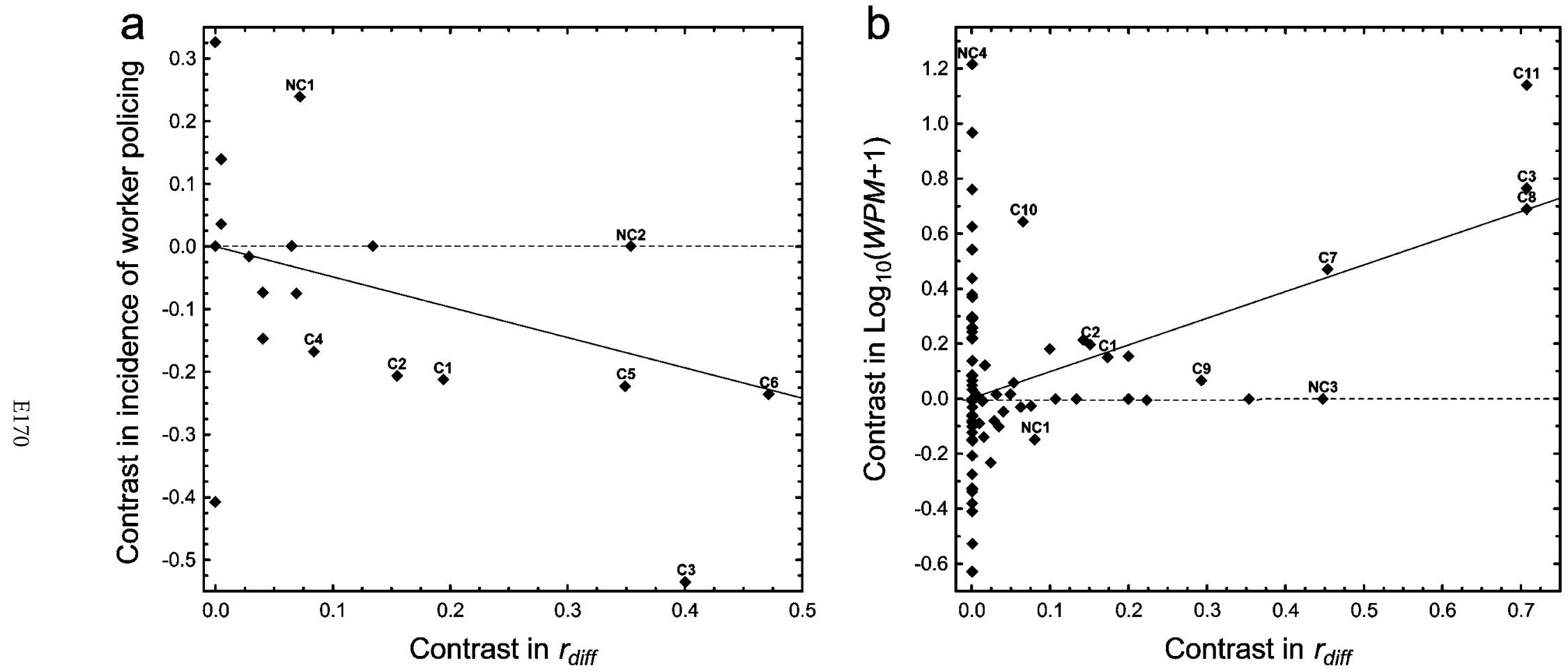

Figure 2: Phylogenetically independent contrast plots. $a$, Across the phylogeny, increases in the relatedness to workers' versus queen's sons ( $\left.r_{\text {diff }}\right)$ are associated with a decreased incidence of worker policing $(\beta=-2.06, t=-2.60, \mathrm{df}$ adj. $=29, P=.007) . b$, Across the phylogeny, increases in the relatedness to workers' versus queen's sons $\left(r_{\text {diff }}\right)$ are associated with significant increases in the percentage of adult males that are workers' sons $(\beta=4.17, t=3.75$, df adj. $=74, P=.0002)$. In both $a$ and $b, r_{\text {diff }}$ is dichotomously coded as 0 and 1 for $r_{\text {diff }}<0$ and $r_{\text {diff }}>0$ and as 0.5 if $r_{\text {dire }}$ was 0 or not significantly different from 0 . In $b$, intraspecific variation is included for Dolichovespula saxonica, where there was significant variation in male parentage between colony classes. Qualitatively similar plots are obtained if all intraspecific variation is included, if intraspecific variation is excluded, if $r_{\text {diff }}$ is continuously coded, or if small studies are excluded (table A2). Lines of regression are forced through the origin. Labeled contrasts are referred to in the text. 
creased incidence of queen policing $(\beta=-0.73$, adjusted $\mathrm{df}=25, t=2.00, P=.03)$. These results also hold if species with indirect relatedness estimates are excluded (queen policing vs. $r_{\text {diff }} r_{\text {diff }}$ continuously or dichotomously coded: $P=.03$ and $P=.0002$, queen vs. worker policing: $P=.0005)$.

\section{Analysis of Male Parentage}

Raw Data. In 75 species where workers are more closely related to other workers' sons than to the queen's sons (table A2), an average of $14 \%$ of the males are workers' sons. By contrast, in 15 species where workers are more closely related to the queen's sons, the percentage is significantly lower $(0.14 \%$; table A2; dependent variable: $\log _{10}[\mathrm{WPM}+1], t$ with separate variance estimates $=$ 7.11, $\mathrm{df}=88$, one-sided $P=.0000000001)$ and never exceeds $2 \%$ (fig. 3). This shows that, in agreement with the relatedness hypothesis, fewer workers' sons are reared in species where workers are less related to workers' sons than to queen's sons. In disagreement with the prediction, however, no workers' sons were detected in 33 out of 75 (44\%) species with $r_{\text {diff }}>0$ (table A2). In part, this could be due to low detection power. In 22 of the 33 species (67\%) without detectable worker reproduction, there were fewer than 50 assignable males (table A2). In addition, worker reproduction was detected significantly more frequently in studies with larger sample sizes (in $32 / 43$ species with $n_{\mathrm{a}}>50$ vs. in $10 / 32$ species with $n_{\mathrm{a}}<50$ :, Fisher's exact test, $P=.0002$ ). More generally, several other factors can select against worker reproduction even when workers are more related to other workers' sons. As a result, these cases do not strongly contradict the relatedness hypothesis (see discussion).

For eight species, there were data on intraspecific variation in male parentage (table A2). In five of these, a lower percentage of the males were workers' sons in colony classes with lower $r_{\text {diff }}$ as predicted (in Bombus hypnorum, D. saxonica, Formica exsecta, Formica rufa, and Lasius niger), but in three species, data went in the opposite direction (in V. rufa, Leptothorax acervorum, and Myrmica tahoensis). However, this cannot be given much weight because these conclusions are based on small sample sizes, and for all except $D$. saxonica, the differences in male parentage between colony classes were not statistically significant (Foster and Ratnieks 2000; table A2). This suggests that facultative worker policing effort as a function of the colony kin structure is rare. The correlation between $r_{\text {diff }}$ and WPM also remained highly significant, irrespective of whether intraspecific variation was included for all eight species $(t=7.27, \mathrm{df}=3.29$, one-sided $P=.001)$ or only for $D$. saxonica $(t=7.20, \mathrm{df}=89$, one-sided $P=$ $.0000000001)$.

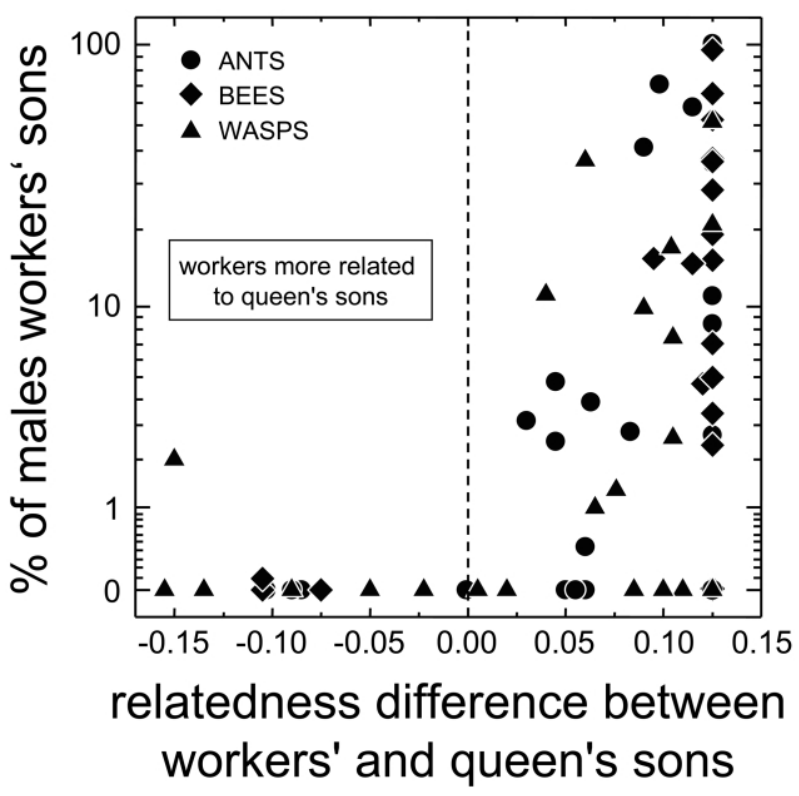

Figure 3: Percentage of males that are workers' sons (on a $\log _{10}[y+$ 1] scale) as a function of the difference in relatedness to workers' sons versus queen's sons in 90 species of eusocial Hymenoptera. Significantly more males are workers' sons when workers are more related to other workers' sons than to the queen's sons ( $t=7.11$, one-sided $P=$ $.0000000001)$. Data points represent species means; intraspecific variation is not shown.

Comparative Analysis. The above conclusions are supported by analyses of phylogenetically independent contrasts. Across the phylogeny (fig. 1b), increases in the relatedness to workers' versus queen's sons $\left(r_{\text {diff }}\right)$ are associated with significant increases in the percentage of adult males that are workers' sons (fig. 2b). The significance level ranges from .002 to .000003 , depending on whether $r_{\text {diff }}$ is continuously or dichotomously coded, intraspecific variation is included, or small studies (with $n_{\mathrm{a}}<50$ ) are excluded (table 1, pt. B). Key contrasts that contribute to the significance of the result are (1) Apis honeybees versus bumblebees and stingless bees (contrast C1 in fig. 2b); (2) Vespula versus Dolichovespula (C2); (3) Vespula squamosa versus V. rufa (C3); (4) Pogonomyrmex rugosus versus Myrmica (C7); (5) Dorylus molestus versus D. quadriceps (C8); (6) Epiponini versus Polistini wasps (C9); (7) Formica versus Polyergus rufescens (C10); and, if intraspecific variation is included, (8) D. saxonica highversus low-paternity colonies (C11, fig. $2 b$ ). In each of these contrasts, the former group in the pair has both lower $r_{\text {diff }}$ and lower WPM. Two contrasts that did not follow the theory as well were (1) Vespula and Dolichovespula versus Vespa (NC1); and (2) higher versus lower Attini ants (NC3). In these cases, worker reproduction was absent 
Table 1: Test for effect of relatedness $\left(r_{\text {diff }}\right)$ on (A) the incidence of worker policing and (B) the percentage of males that are workers' sons in analyses that control for phylogenetic nonindependence

\begin{tabular}{|c|c|c|c|c|c|c|c|c|c|c|c|}
\hline$r_{\text {diff }}$ test & $\begin{array}{l}\text { No. } \\
\text { species }\end{array}$ & $\begin{array}{l}\text { No. } \\
\text { contrasts }\end{array}$ & $\begin{array}{l}\text { No. } \\
\text { polytomies } \\
\text { in phylogeny }\end{array}$ & $\begin{array}{l}\text { Adjusted } \\
\text { df }\end{array}$ & Slope & $t$ & $\begin{array}{c}P \\
\text { (one-tailed) }\end{array}$ & \multicolumn{2}{|c|}{$\begin{array}{l}\text { Expected } \\
\text { slope }\end{array}$} & \multicolumn{2}{|c|}{$\begin{array}{l}\text { Effect size } \\
\quad(\%)\end{array}$} \\
\hline \multicolumn{12}{|l|}{ A. Incidence of worker policing: } \\
\hline Continuously coded, all species included & 41 & 40 & 10 & 29 & -2.06 & -2.60 & .007 & \multicolumn{2}{|c|}{-4.74} & \multicolumn{2}{|c|}{43.38} \\
\hline \multicolumn{12}{|l|}{ Continuously coded, species with indirect relatedness estimates } \\
\hline excluded & 35 & 34 & 5 & 28 & -2.07 & -2.45 & .01 & \multicolumn{2}{|c|}{-4.61} & \multicolumn{2}{|c|}{44.95} \\
\hline Dichotomously coded, all species included & 41 & 40 & 10 & 29 & -.49 & -3.80 & .0003 & \multicolumn{2}{|c|}{-1.00} & \multicolumn{2}{|c|}{49.40} \\
\hline $\begin{array}{l}\text { Dichotomously coded, species with indirect relatedness } \\
\text { estimates excluded } \\
\text { Average }\end{array}$ & 35 & 34 & 5 & 28 & -.51 & -3.59 & .0006 & \multicolumn{2}{|c|}{-1.00} & \multicolumn{2}{|c|}{$\begin{array}{l}50.60 \\
47.08\end{array}$} \\
\hline Average & & & & & & & & \multicolumn{4}{|c|}{$\begin{array}{l}\text { Assuming WPM for } \\
\text { species with } r_{\text {diff }}>0 \text { of }\end{array}$} \\
\hline B. Percentage of males that are workers' sons $\left(\log _{10}[\mathrm{WPM}+1]\right)$ : & & & & & & & & $10 \%$ & $100 \%$ & $10 \%$ & $100 \%$ \\
\hline Continuously coded, using species averages & 90 & 89 & 15 & 73 & 3.26 & 2.92 & .002 & $\overline{4.71}$ & 9.14 & 69.31 & 35.69 \\
\hline Continuously coded, all intraspecific variation included & 98 & 97 & 15 & 81 & 2.78 & 3.14 & .001 & 5.75 & 10.89 & 7.37 & 3.89 \\
\hline $\begin{array}{l}\text { Continuously coded, intraspecific variation included only when } \\
\text { significant }\end{array}$ & 91 & 90 & 15 & 74 & 4.17 & 3.75 & .0002 & 5.14 & 9.98 & 81.08 & 41.80 \\
\hline $\begin{array}{l}\text { Continuously coded, using species averages, all small studies } \\
\text { excluded }\left(n_{\mathrm{a}}<50\right)\end{array}$ & 57 & 56 & 4 & 51 & 5.18 & 4.18 & .00005 & 4.65 & 9.02 & 111.44 & 57.46 \\
\hline Continuously coded, using species averages, small studies & & & & & & & & & & & \\
\hline excluded when $\mathrm{WPM}=0$ & 68 & 67 & 9 & 57 & 4.08 & 3.94 & .0001 & 4.83 & 9.37 & 84.41 & 43.49 \\
\hline Dichotomously coded, using species averages & 90 & 89 & 15 & 73 & .77 & 3.55 & .0003 & 1.06 & 2.07 & 72.17 & 36.96 \\
\hline Dichotomously coded, all intraspecific variation included & 98 & 97 & 15 & 81 & .42 & 3.06 & .002 & 1.02 & 1.96 & 41.37 & 21.66 \\
\hline $\begin{array}{l}\text { Dichotomously coded, intraspecific variation included only } \\
\text { when significant }\end{array}$ & 91 & 90 & 15 & 74 & .93 & 4.89 & .000003 & 1.06 & 2.05 & 87.57 & 45.28 \\
\hline $\begin{array}{l}\text { Dichotomously coded, using species averages, all small studies } \\
\text { excluded }\left(n_{\mathrm{a}}<50\right)\end{array}$ & 57 & 56 & 4 & 51 & .90 & 3.52 & .0005 & 1.06 & 2.06 & 85.00 & 43.74 \\
\hline $\begin{array}{l}\text { Dichotomously coded, using species averages, small studies } \\
\text { excluded when WPM }=0 \\
\text { Average }\end{array}$ & 68 & 67 & 9 & 57 & .79 & 3.89 & .0001 & 1.06 & 2.07 & $\begin{array}{l}74.72 \\
71.44\end{array}$ & $\begin{array}{l}38.26 \\
36.82\end{array}$ \\
\hline
\end{tabular}

Note: Effect sizes are calculated as a percentage of the slopes expected under a perfect fit with the theory. 
in the latter group of the pair despite $r_{\text {diff }}$ being higher. In addition, there were often large contrasts in WPM despite the contrast in $r_{\text {diff }}$ being 0 , such as in the sibling species Polistes gallicus and Polistes chinesis, which both had $r_{\text {diff }}=0.125$ but had WPM $=0 \%$ and $51.1 \%$, respectively (contrast NC4 in fig. 2b). This implies that factors other than relatedness also cause significant variation in male parentage. Overall, however, relatedness had a reasonably high predictive power, with effect sizes being moderately large (average effect sizes $71 \%$ and $37 \%$, assuming values for WPM of $10 \%$ and $100 \%$ for species with $r_{\text {diff }}>0$; table 1 , pt. B). The only tests where effect sizes were small $(<30 \%)$ was when all intraspecific variation was included (table 1, pt. B). This reflects the fact that there was little evidence in our data set for levels of worker policing being facultatively adjusted in function of the colony kin structure.

\section{Discussion}

The two comparative analyses we presented provide strong support for the relatedness hypothesis of worker policing (Ratnieks 1988). First, an analysis of behavioral data confirmed that worker policing occurs more frequently in species where workers are more related to the queen's sons (WP present in $7 / 7$ species) than in species where they are more or equally related to other workers' offspring $(7 / 7$ vs. only $7 / 34$ species). Second, the analysis of male parentage showed that, as predicted, a significantly higher percentage of the males are workers' sons in 75 species where the workers are more related to other workers' sons (average 14\%) than in 15 species where they are more related to the queen's sons (average $0.14 \%$ ). These correlations were also significant when phylogenetic nonindependence was controlled for (table 1; fig. 2). Overall, the effect of relatedness was moderately large, approximately half that expected for a perfect fit with the theory (table 1). In addition, a difference of $14 \%$ versus $0.14 \%$ is, in fact, large, as it represents a difference of two orders of magnitude.

The strong support we found for the relatedness hypothesis contrasts with Hammond and Keller (2004), who found no association between relatedness and male parentage. This is probably because their analysis was based on a smaller data set of only 50 species and had a lower statistical power than the current one. In fact, with the observed effect size of $50 \%$ and with intraspecific variation excluded, the Hammond and Keller (2004) analysis only had a power of approximately $20 \%$. The Hammond and Keller (2004) analysis also only included two taxa with $r_{\text {diff }}<0$ (Epiponini wasps and Apis honeybees). By comparison, our two analyses combined were based on 109 species of ants, bees, and wasps and included seven taxa with $r_{\text {diff }}<0$. This makes our data set much more suitable to test the relatedness hypothesis and in fact is the largest ever used to test a prediction from kin selection theory. Slight differences in our analysis compared with that of Hammond and Keller (2004) or the use of more accurate estimates for some species did not contribute to the difference in conclusion. In fact, an analysis following our methods on the taxa included in Hammond and Keller (2004) confirms that the effect of relatedness then remains nonsignificant.

The best support for the relatedness hypothesis is given by the fact that the percentage of adult males that are workers' sons was always very low in the 15 species where workers were more related to the queen's sons (four Apis honeybees, three Epiponini wasps, three Vespula wasps, multiple paternity colonies of Dolichovespula saxonica, and four ants; table A2) and that in five of these species, worker policing has also been demonstrated through direct behavioral observation (in three Apis honeybees, Vespula germanica, and Acromyrmex echinatior, table A1). In addition, worker policing has also been shown in a sixth species where workers are more related to the queen's sons, the polyandrous ponerine ant Pachycondyla inversa (D'Ettorre et al. 2004; see table A1). In the Epiponini wasps, however, worker policing remains to be directly shown (table A2).

It is important to realize that the relatedness hypothesis for worker policing is the only theory that predicts fewer workers' sons when the relatedness among the workers decreases (Ratnieks 1988). In fact, in the absence of worker policing, theory shows that lower relatedness among workers should lead to more rather than less worker reproduction. This is because the evolutionarily stable strategy proportion of egg-laying workers increases when reproductive competition is among less related nestmate workers (Wenseleers et al. 2004a, 2004b; also see Bourke 1988b).

The reverse prediction, that worker policing should be absent in species where workers are more related to other workers' sons, thereby leading to the rearing of many workers' sons, is less well supported (tables A1, A2). In line with the theory, in stingless bees, halictid bees, and bumblebees, which have queens that are typically single mated, worker policing is absent, and in most species a significant percentage of the males are the workers' sons (tables A1, A2). Similarly, in the ants Crematogaster smithi, Dinoponera quadriceps, Myrmica punctiventris, Myrmica tahoensis, Polyergus rufescens, and Protomognathus americanus, where queens are predominantly single mated, and in the low-paternity Vespidae wasps Dolichovespula, Polistes chinensis, and Vespula rufa, worker reproduction can also reach very high levels (table A2). Conversely, however, worker reproduction was not detected in 33 out of 75 (44\%) species where workers were more related to other workers' sons (table A2). As mentioned above, for some 
species this could merely reflect low detection power, because in 22 of these 33 species, there were fewer than 50 assignable males (table A2). However, it seems unlikely that this can explain all cases. For example, in the singlepaternity stingless bees Melipona beecheii and Schwarziana quadripunctata and the hornet Vespa ducalis, absence of worker-produced adult males is well supported (table A2). Furthermore, worker policing has also been directly observed in some species with single-mated or predominantly single-mated queens, including the hornet Vespa crabro (Foster et al. 2002) and the ants Aphaenogaster smythiesi (Iwanishi et al. 2003), Camponotus floridanus (Endler et al. 2004), and Diacamma sp. (Kikuta and Tsuji 1999). Worker policing has even been found in species that reproduce parthenogenetically: the ant Platythyrea punctata (Hartmann et al. 2003) and the Cape honeybee Apis mellifera capensis (Pirk et al. 2003; but also see Moritz et al. 1999; Beekman et al. 2002) and also in two species where workers are equally related to the queen's sons as to other workers' sons (Vespula vulgaris and Formica fusca). In these cases, worker policing is selectively neutral on relatedness grounds.

The above results show that although relatedness explains a good part of the variation in male parentage and worker policing behavior, there is also much residual variation. This implies that factors other than relatedness also must be important. Below, we give a list of the likely factors involved, all of which in fact are consistent with kin selection theory.

\section{Queen Policing}

There is abundant evidence that the queen may police worker-laid eggs or aggress egg-laying workers (table A2). Queen policing is well supported in 30 species of ants, bees, and wasps with known colony kin structure (table A1), and it is particularly common in small-colony species, including Halictidae bees (Michener and Brothers 1974), bumblebees (e.g., Free et al. 1969; Duchateau 1989), stingless bees (e.g., Sakagami and Oniki 1963; Bego 1990), and small-colony Polistinae and Vespinae wasps (e.g., Saigo and Tsuchida 2004; Wenseleers et al. 2005a, 2005b; table A1). Our analysis also showed that queen policing was significantly more common in species where workers are more related to other workers' sons and in species where worker policing does not occur. This is as expected, given that the benefits for the queen to police are greatest when the workers do not police each other. Alternatively, the correlation could also be mediated by colony size, because species with worker policing and multiple-mated queens usually have large colonies (e.g., Apis and all Vespula except V. rufa, Acromyrmex, and Dorylus), where it would be difficult for the queen to police all worker re- production. Queen policing strongly counteracts the prediction that many of the males should be workers' sons in species where workers are more related to other workers' sons. Indeed, in some species, it has been shown that queen policing may result in an almost complete prevention of worker reproduction. For example, in the paper wasp Polistes dominulus and in the bumblebee Bombus terrestris, the queen removes nearly all worker-laid eggs (Duchateau 1989; Velthuis et al. 2002; Liebig et al. 2005). Theory has shown that effective queen policing can cause workers to refrain from reproducing in the first place (Wenseleers et al. 2004a, 2004b). In line with this idea, a comparative analysis of nine wasps and the honeybee has shown that more effective policing causes fewer workers to lay eggs (Wenseleers and Ratnieks 2006). In addition, it is thought that in stingless bees, a long history of queen policing has caused workers in many species to lay only inviable trophic eggs or even to become obligately sterile (Bego 1990; Crespi 1992; Wenseleers et al. 2004a).

\section{Worker Matricide}

In some of the low-paternity species with annual societies, worker reproduction does occur but comes about by the workers first killing the queen near the end of the colony life cycle ("worker matricide"; Bourke 1994). If worker reproduction only occurs after the queen has been killed, it would have remained undetected in our data set, as we only analyzed worker reproduction in colonies with a queen. Similar to the relatedness hypothesis of worker policing, matricide is expected to be more common in singlepaternity species, where collective worker interests favor worker reproduction (Bourke 1994). In support of this, queenless colonies appear to be more frequent in Vespinae wasp species where queens are predominantly singlemated (Foster and Ratnieks 2001c). In addition, worker matricide has been directly observed in the hornet V. crabro (Janet 1895), in the tree wasp Dolichovespula sylvestris (T. Wenseleers, A. Tofiliski, F. S. Nascimento, and F. L. W. Ratnieks, unpublished manuscript), and in several bumblebees (van Honk 1982; Bourke 1994), and is suspected in the paper wasp Polistes gallicus (Strassmann et al. 2003). All these typically have single-mated queens (table A1). In the hornet $V$. crabro, workers from queenright nests have also been observed leaving the nest and building a small nest nearby where they then rear their own males (Hamilton 1972, p. 209; Bourke 1988b).

\section{Worker-Dominance Behavior Limits Successful Worker Reproduction}

Dominance behavior and mutual egg eating among reproductive workers is widespread (table A1), and this can 
also limit successful worker reproduction. For example, in the tree wasp $D$. sylvestris, egg-laying workers selectively eat and replace other workers' eggs (T. Wenseleers, A. Tofilski, F. S. Nascimento, and F. L. W. Ratnieks, unpublished manuscript). Because the queen's eggs are not replaced and the workers mutually destroy each other's brood, the queen's share of male production is actually increased. Hence, mutual egg eating among egg-laying workers can have an effect similar to normal worker policing by nonegg-laying workers despite being selected for purely selfish reasons-to replace nephews by sons, which is always favored (T. Wenseleers, A. Tofilski, F. S. Nascimento, and F. L. W. Ratnieks, unpublished manuscript). Aggressive dominance hierarchies among the workers can similarly limit successful worker reproduction to just one or a few workers (Heinze et al. 1997; table A1).

\section{Workers Can Be Selected to Police Each Other or Refrain from Laying Eggs Even under Single Mating}

Finally, there are also several factors that can select for workers to police each other or to refrain from laying eggs, even when they are more related to other workers' sons. There are two factors that can cause this.

Colony-Level Costs of Worker Reproduction. Worker reproduction frequently has a colony-level cost, because reproductive workers usually work less or not at all (e.g., Cole 1986; reviewed in Wenseleers et al. 2004b) or because worker reproduction may result in inefficiencies in brood rearing, such as when many more male eggs are laid than can be reared (Wenseleers et al. 2004b). As a result, worker policing can have colony-level benefits, particularly if policing occurs through aggression and causes reproductive workers to work rather than reproduce (e.g., in A. smythiesi [Iwanishi et al. 2003] and P. punctata [Hartmann et al. 2003]). Theory has shown that if worker policing has colony-level benefits, it can be selected for even under single mating (Ratnieks 1988). Theory has shown that when worker reproduction has a very high colony-level cost, it can also select for workers to completely refrain from egg laying (Cole 1986; Wenseleers et al. 2004b). Nevertheless, an inclusive fitness model showed that under single mating, such self-restraint can occur only when a single reproductive worker would reduce colony productivity by more than $25 \%$ (Wenseleers et al. 2004b). This is unlikely for most species, except for those with extremely small colonies in which the cost exacted by a single nonworking reproductive worker might indeed be as high as 25\% (e.g., in the Sphecid wasp Microstigmus comes, which can have colonies of only three or four females [Ross and Matthews 1989]).

In another efficiency-based argument, Pirk et al. (2004) have argued that worker-laid eggs in the honeybee are inviable and that worker policing can be explained simply as the removal of dead (worker-laid) eggs. This hypothesis, however, is weak for several reasons (Beekman and Oldroyd 2005). First, research has shown that in both the honeybee and the common wasp, worker-laid eggs normally do not have lower viability than queen-laid eggs (Ratnieks and Visscher 1989; Beekman and Oldroyd 2005; Helanterä et al. 2006). Second, in the honeybee, egg viability has been shown not to affect policing because queenlaid eggs that have been killed by suffocation with $\mathrm{CO}_{2}$ gas are not policed (Beekman and Oldroyd 2005). Finally, worker-laid eggs are routinely reared in queenless colonies of many species (Bourke 1988b).

Interaction with Queen-Worker Conflict over the Sex Ratio. Theory has shown that worker policing may also be selected for under single mating if it allows the workers to bias the sex ratio toward females (the worker optimum; Trivers and Hare 1976) at low cost by the removal of worker-laid eggs, which are exclusively male (Foster and Ratnieks 2001b). A preliminary model has shown that sex ratio costs can, under some circumstances, even select workers to refrain from laying eggs (T. Wenseleers and P. Pamilo, in preparation). Sex ratio benefits are particularly likely in ants and Vespidae wasps where the rearing of workers' sons is traded off against the rearing of the queen's offspring of both sexes, as in these species brood are reared in piles (ants) or in the same cells (wasps). In contrast, in the honeybee, males are reared in special large cells so that the elimination of a worker-laid egg from a cell provides an opportunity for the rearing of a queen's son.

Sex ratio considerations are also likely to explain why worker policing is generally not facultatively expressed as a function of the colony kin structure. Facultative adjustment of the sex ratio as a function of the colony kin structure is well known in social Hymenoptera (Queller and Strassmann 1998; Bourke 2005). For example, in the wood ants Formica truncorum and Formica exsecta, workers enhance their inclusive fitness by specializing in the rearing of queens in colonies headed by a single-mated queen versus males in colonies headed by a multiple-mated queen (Sundström 1994; Sundström et al. 1996). This pattern of facultative sex ratio adjustment results in a situation that selects against worker reproduction, because in single paternity nests, queen but not male production is favored, and in multiple paternity nests, worker policing is expected (Walin et al. 1998; Foster and Ratnieks 2001b).

\section{Conclusion}

In sum, our comparative analyses clearly demonstrate that relatedness plays an important role in determining male 
parentage in social Hymenoptera, with workers generally tending to rear males to which they are more related. Thus, our analyses provide excellent support for both worker policing theory and, more generally, kin selection (Hamilton 1964; Ratnieks 1988). Nevertheless, the relatedness asymmetry to workers' versus queen's sons is not the only determining factor, and as we have argued, at least five other factors can also favor worker policing or cause worker reproduction to be absent in queenright colonies, even in species with single-mated queens. One of these, costs of worker reproduction at the colony level, was part of the original theoretical article that also presented the relatedness argument for worker policing (Ratnieks 1988). Another factor, worker policing to bias the sex ratio, is a more recent idea (Foster and Ratnieks 2001b). Other longknown factors, such as worker-dominance behavior (Heinze et al. 1997), queen matricide (Bourke 1994), and queen policing (Oster and Wilson 1978; Ratnieks et al. 2006), are also very relevant. An important task for the future remains to determine which of these factors are most relevant in particular species in setting observed levels of male production by workers. Doing so will likely lead to a better understanding of the great variation in male production by workers that exists among species that have single-mated queens.

\section{Note Added in Proof}

Recently, Moreau et al. (2006) have constructed a detailed molecular phylogeny of ants. The phylogenetic relationships given are slightly different than in figure 1 . Nevertheless, using the phylogenetic relationships of Moreau et al. (2006) does not qualitatively change any of our conclusions.

\section{Acknowledgments}

This work was supported by the "INSECTS" European Union Training and Mobility of Researchers network and by fellowships from the European Union Marie-Curie program and the Fund for Scientific Research-Flanders to T.W. We thank M. Brown, M. Dijkstra, A. Dollin, P. D'Ettorre, J. Evans, K. Foster, M. Goodisman, M. Henshaw, D. Kronauer, R. Paxton, P. Seppä, N. Stroeymeyt, L. Sundström, and K. Tsuchida for help in compiling the data. We also thank A. Bourke, R. Hammond, L. Keller, P. Nonacs, and D. Queller for constructive comments. Finally, we would like to thank the library personnel of the Institute for Advanced Study in Berlin for providing us with many of the references.

\section{Literature Cited}

Alexander, B. A., and C. D. Michener. 1995. Phylogenetic studies of the families of short-tongued bees (Hymenoptera: Apoidea). University of Kansas Scientific Bulletin 55:377-424.

Arévalo, E., Y. Zhu, J. M. Carpenter, and J. E. Strassmann. 2004. The phylogeny of the social wasp subfamily Polistinae: evidence from microsatellite flanking sequences, mitochondrial COI sequence, and morphological characters. BMC Evolutionary Biology 4:1-16.

Arias, M. C., and W. S. Sheppard. 2005. Phylogenetic relationships of honey bees (Hymenoptera:Apinae:Apini) inferred from nuclear and mitochondrial DNA sequence data. Molecular Phylogenetics and Evolution 37:25-35.

Ascher, J. S., B. N. Danforth, and S. Ji. 2001. Phylogenetic utility of the major opsin in bees (Hymenoptera: Apoidea): a reassessment. Molecular Phylogenetics and Evolution 19:76-93.

Baroni Urbani, C., B. Bolton, and P. S. Ward. 1992. The internal phylogeny of ants (Hymenoptera: Formicidae). Systematic Entomology 17:301-329.

Beekman, M., and B. P. Oldroyd. 2005. Honey bee workers use cues other than egg viability for policing. Biology Letters 1:129-132.

Beekman, M., G. Good, M. H. Allsopp, S. Radloff, C. W. W. Pirk, and F. L. W. Ratnieks. 2002. A non-policing honey bee colony (Apis mellifera capensis). Naturwissenschaften 89:479-482.

Bego, L. R. 1990. On social regulation in Nannotrigona (Scaptotrigona) postica Latreille with special reference to productivity of colonies (Hymenoptera, Apidae, Meliponinae). Revista Brasileira de Entomologia 34:721-738.

Beibl, J., R. J. Stuart, J. Heinze, and S. Foitzik. 2005. Six origins of slavery in formicoxenine ants. Insectes Sociaux 52:291-297.

Bourke, A. F. G. $1988 b$. Worker reproduction in the higher eusocial Hymenoptera. Quarterly Review of Biology 63:291-311.

- 1994. Worker matricide in social bees and wasps. Journal of Theoretical Biology 167:283-292.

- 2005. Genetics, relatedness and social behaviour in insect societies, Pages 1-30 in M. D. E. Fellowes, G. J. Holloway, and J. Rolff, eds. Insect evolutionary ecology. CABI, Wallingford.

Cameron, S. A., and P. Mardulyn. 2001. Multiple molecular data sets suggest independent origins of highly eusocial behavior in bees (Hymenoptera: Apinae). Systematic Biology 50:194-214.

Carpenter, J. M., and E. P. Perera. 2006. Phylogenetic relationships among yellowjackets and the evolution of social parasitism (Hymenoptera: Vespidae, Vespinae). American Museum Novitates 3507:1-19.

Cole, B. J. 1986. The social behavior of Leptothorax allardycei (Hymenoptera, formicidae): time budgets and the evolution of worker reproduction. Behavioral Ecology and Sociobiology 18:165-173.

Contel, E. P. B., and W. E. Kerr. 1976. Origin of males in Melipona subnitida estimated from data of an isozymic polymorphic system. Genetica 46:271-279.

Crespi, B. J. 1992. Cannibalism and trophic eggs in subsocial and eusocial insects. Pages 176-213 in M. A. Elgar, and Bernard J. Crespi, eds. Cannibalism: ecology and evolution among diverse taxa. Oxford University Press, Oxford.

Crozier, R. H., and P. Pamilo. 1996. Evolution of social insect colonies: sex allocation and kin selection. Oxford University Press, Oxford.

D’Ettorre, P., J. Heinze, and F. L. W. Ratnieks. 2004. Worker policing by egg-eating in the ponerine ant Pachycondyla inversa. Proceedings of the Royal Society B: Biological Sciences 271:1427-1434. 
Duchateau, M. J. 1989. Agonistic behaviour in colonies of the bumblebee Bombus terrestris. Journal of Ethology 7:141-151.

Endler, A., J. Liebig, T. Schmitt, J. E. Parker, G. R. Jones, P. Schreier, and B. Hölldobler. 2004. Surface hydrocarbons of queen eggs regulate worker reproduction in a social insect. Proceedings of the National Academy of Sciences of the USA 101:2945-2950.

Engel, M. S. 2001. Monophyly and extensive extinction of advanced eusocial bees: insights from an unexpected Eocene diversity. Proceedings of the National Academy of Sciences of the USA 98:16611664.

Felsenstein, J. 1985. Phylogenies and the comparative method. American Naturalist 125:1-15.

Foster, K. R., and F. L. W. Ratnieks. 2000. Facultative worker policing in a wasp. Nature 407:692-693.

2001a. Convergent evolution of worker policing by egg eating in the honeybee and common wasp. Proceedings of the Royal Society B: Biological Sciences 268:169-174.

- 2001b. The effect of sex-allocation biasing on the evolution of worker policing in hymenopteran societies. American Naturalist 158:615-623.

-2001c. Paternity, reproduction and conflict in vespine wasps: a model system for testing kin selection predictions. Behavioral Ecology and Sociobiology 50:1-8.

Foster, K. R., and T. Wenseleers. 2006. A general model for the evolution of mutualisms. Journal of Evolutionary Biology 19:12831293.

Foster, K. R., F. L. W. Ratnieks, N. Gyllenstrand, and P. A. Thoren. 2001. Colony kin structure and male production in Dolichovespula wasps. Molecular Ecology 10:1003-1010.

Foster, K. R., J. Gulliver, and F. L. W. Ratnieks. 2002. Worker policing in the European hornet Vespa crabro. Insectes Sociaux 49:41-44.

Frank, S. A. 1995. Mutual policing and repression of competition in the evolution of cooperative groups. Nature 377:520-522.

. 2003. Repression of competition and the evolution of cooperation. Evolution 57:693-705.

Free, J. B., I. Weinberg, and A. Whiten. 1969. The egg-eating behaviour of Bombus lapidarius L. Behaviour 35:313-317.

Gadagkar, K. 2004. Why do honey bee workers destroy each other's eggs? Journal of Biosciences 29:213-217.

Garland, T., Jr., and A. R. Ives. 2000. Using the past to predict the present: confidence intervals for regression equations in phylogenetic comparative methods. American Naturalist 155:346-364.

Garland, T., Jr., P. H. Harvey, and A. R. Ives. 1992. Procedures for the analysis of comparative data using phylogenetically independent contrasts. Systematic Biology 41:18-32.

Garland, T., Jr., A. W. Dickerman, C. M. Janis, and J. A. Jones. 1993. Phylogenetic analysis of covariance by computer simulation. Systematic Biology 42:265-292.

Garland, T., Jr., P. E. Midford, and A. R. Ives. 1999. An introduction to phylogenetically based statistical methods, with a new method for confidence intervals on ancestral values. American Zoologist 39:374-388.

Grafen, A. 1989. The phylogenetic regression. Philosophical Transactions of the Royal Society B: Biological Sciences 326:119-157.

Grafen, A., and M. Ridley. 1996. Statistical tests for discrete crossspecies data. Journal of Theoretical Biology 183:255-267.

Halling, L. A., B. P. Oldroyd, W. Wattanachaiyingcharoen, A. B. Barron, P. Nanork, and S. Wongsiri. 2001. Worker policing in the bee Apis florea. Behavioral Ecology and Sociobiology 49:509-513.
Hamilton, W. D. 1964. The genetical evolution of social behaviour. I, II. Journal of Theoretical Biology 7:1-52.

. 1972. Altruism and related phenomena, mainly in social insects. Annual Review of Ecology and Systematics 3:193-232.

Hammerstein, P. 2003. Genetic and cultural evolution of cooperation. MIT Press, Cambridge, MA.

Hammond, R. L., and L. Keller. 2004. Conflict over male parentage in social insects. PLoS Biology 2:1-11.

Hardin, G. 1968. The tragedy of the commons. Science 162:12431244.

Hartmann, A., J. Wantia, J. A. Torres, and J. Heinze. 2003. Worker policing without genetic conflicts in a clonal ant. Proceedings of the National Academy of Sciences of the USA 100:12836-12840.

Hastings, M. D., D. C. Queller, F. Eischen, and J. E. Strassmann. 1998. Kin selection, relatedness, and worker control of reproduction in a large-colony epiponine wasp, Brachygastra mellifica. Behavioral Ecology 9:573-581.

Heinze, J., W. Puchinger, and B. Hölldobler. 1997. Worker reproduction and social hierarchies in Leptothorax ants. Animal Behaviour 54:849-864.

Helanterä, H., A. Tofilski, T. Wenseleers, and F. L. W. Ratnieks. 2006. Worker policing in the common wasp Vespula vulgaris is not aimed at improving colony hygiene. Insectes Sociaux (forthcoming).

Housworth, E. A., E. P. Martins, and M. Lynch. 2004. The phylogenetic mixed model. American Naturalist 163:84-96.

Iwanishi, S., E. Hasegawa, and K. Ohkawara. 2003. Worker oviposition and policing behaviour in the myrmicine ant Aphaenogaster smythiesi japonica Forel. Animal Behaviour 66:513-519.

Janet, C. 1895. Etudes sur les fourmis, les guêpes et les abeilles. No. 9. Sur Vespa crabro L.: histoire d'un nid depuis son origine. Extrait des Mémoires de la Société zoologique de France, vol. 8. Société Entomologique de France, Paris.

Kawakita, A., T. Sota, M. Ito, J. S. Ascher, H. Tanaka, M. Kato, and D. W. Roubik. 2004. Phylogeny, historical biogeography, and character evolution in bumble bees (Bombus: Apidae) based on simultaneous analysis of three nuclear gene sequences. Molecular Phylogenetics and Evolution 31:799-804.

Keller, L. 1999. Levels of selection in evolution. Princeton University Press, Princeton, NJ.

Kikuta, N., and K. Tsuji. 1999. Queen and worker policing in the monogynous and monandrous ant, Diacamma sp. Behavioral Ecology and Sociobiology 46:180-189.

Koedam, D., O. I. Cepada, and V.-L. Imperatriz-Fonseca. 2007. Reproduction and oophagy by workers in the polygynous stingless bee Melipona bicolor (Hymenoptera: Meliponini). Apidologie (forthcoming).

Leigh, E. G. J. 1977. How does selection reconcile individual advantage with the good of the group? Proceedings of the National Academy of Sciences of the USA 74:4542-4546.

Liebig, J., T. Monnin, and S. Turillazzi. 2005. Direct assessment of queen quality and lack of worker suppression in a paper wasp. Proceedings of the Royal Society B: Biological Sciences 272:13391344.

Maddison, W. P., and D. R. Maddison. 2004. Mesquite: a modular system for evolutionary analysis. Version 1.03. http:// mesquiteproject.org.

Martins, E. P., and T. F. Hansen. 1997. Phylogenies and the comparative method: a general approach to incorporating phylogenetic information into the analysis of interspecific data. American Naturalist 149:646-667. 
Martins, E. P., J. A. F. Diniz-Filho, and E. A. Housworth. 2002. Adaptive constraints and the phylogenetic comparative method: a computer simulation test. Evolution 56:1-13.

Michener, C. D., and D. J. Brothers. 1974. Were workers of eusocial Hymenoptera initially altruistic or oppressed? Proceedings of the National Academy of Sciences of the USA 71:671-674.

Midford, P. E., T. Garland Jr., and W. P. Maddison. 2003. PDAP package of mesquite. http://mesquiteproject.org/pdap_mesquite/ index.html.

Monnin, T., and C. Peeters. 1997. Cannibalism of subordinates' eggs in the monogynous queenless ant Dinoponera quadriceps. Naturwissenschaften 84:499-502.

Monnin, T., and F. L. W. Ratnieks. 2001. Policing in queenless ponerine ants. Behavioral Ecology and Sociobiology 50:97-108.

Moreau, C. S., C. D. Bell, R. Vila, S. B. Archibald, and N. E. Pierce. 2006. Phylogeny of the ants: diversification in the age of angiosperms. Science 312:101-104.

Moritz, R. F. A., P. Kryger, and M. H. Allsopp. 1999. Lack of worker policing in the Cape honeybee (Apis mellifera capensis). Behaviour 136:1079-1092.

Oldroyd, B. P., L. A. Halling, G. Good, W. Wattanachaiyingcharoen, A. B. Barron, P. Nanork, S. Wongsiri, et al. 2001. Worker policing and worker reproduction in Apis cerana. Behavioral Ecology and Sociobiology 50:371-377.

Oster, G. F., and E. O. Wilson. 1978. Caste and ecology in the social insects. Princeton University Press, Princeton, NJ.

Owen, R. E., and R. C. Plowright. 1982. Worker-queen conflict and male parentage in bumble bees. Behavioral Ecology and Sociobiology 11:91-99.

Pagel, M. D. 1992. A method for the analysis of comparative data. Journal of Theoretical Biology 156:431-442.

Palmer, K. A., and B. P. Oldroyd. 2000. Evolution of multiple mating in the genus Apis. Apidologie 31:235-248.

Pamilo, P. 1991. Evolution of colony characteristics in social insects. 2. Number of reproductive individuals. American Naturalist 138: 412-433.

Pickett, K. M., and J. W. Wenzel. 2004. Phylogenetic analysis of the New World Polistes (Hymenoptera: Vespidae: Polistinae) using morphology and molecules. Journal of the Kansas Entomological Society 77:742-760.

Pirk, C. W. W., P. Neumann, and F. L. W. Ratnieks. 2003. Cape honeybees, Apis mellifera capensis, police worker-laid eggs despite the absence of relatedness benefits. Behavioral Ecology 14:347352.

Pirk, C. W. W., P. Neumann, R. Hepburn, R. F. A. Moritz, and J. Tautz. 2004. Egg viability and worker policing in honey bees. Proceedings of the National Academy of Sciences of the USA 101: 8649-8651.

Purvis, A., and T. J. Garland. 1993. Polytomies in comparative analyses of continuous characters. Systematic Biology 42:569-575.

Queller, D. C., and J. E. Strassmann. 1998. Kin selection and social insects. BioScience 48:165-175.

Ratnieks, F. L. W. 1988. Reproductive harmony via mutual policing by workers in eusocial Hymenoptera. American Naturalist 132: 217-236.

Ratnieks, F. L. W., and P. K. Visscher. 1989. Worker policing in the honeybee. Nature 342:796-797.

Ratnieks, F. L. W., and T. Wenseleers. 2005. Policing insect societies. Science 307:54-56.

Ratnieks, F. L. W., K. R. Foster, and T. Wenseleers. 2006. Conflict resolution in insect societies. Annual Review of Entomology 51: 581-608.

Ross, K. G., and R. W. Matthews. 1989. Population genetic structure and social evolution in the Sphecid wasp Microstigmus comes. American Naturalist 134:574-598.

Saigo, T., and K. Tsuchida. 2004. Queen and worker policing in monogynous and monandrous colonies of a primitively eusocial wasp. Proceedings of the Royal Society B: Biological Sciences 271(suppl.):S509-S512.

Sakagami, S. F., and Y. Oniki. 1963. Behavior studies of the stingless bees, with special reference to the oviposition process. I. Melipona compressipes manaosensis Schwarz. Journal of the Faculty of Science Hokkaido University Series VI Zoology 15:300-318.

Saux, C., B. L. Fisher, and G. S. Spicer. 2004. Dracula ant phylogeny as inferred by nuclear $28 \mathrm{~S}$ rDNA sequences and implications for ant systematics (Hymenoptera: Formicidae: Amblyoponinae). Molecular Phylogenetics and Evolution 33:457-468.

Schultz, T. R., M. S. Engel, and J. S. Ascher. 2001. Evidence for the origin of eusociality in the corbiculate bees (Hymenoptera: Apidae). Journal of the Kansas Entomological Society 74:10-16.

Starr, C. K. 1984. Sperm competition, kinship, and sociality: a review of modern theory. Pages 427-464 in R. L. Smith, ed. Sperm competition and the evolution of animal mating systems. Academic Press, Orlando, FL.

Strassmann, J. E., J. S. Nguyen, E. Arevalo, R. Cervo, F. Zacchi, S. Turillazzi, and D. C. Queller. 2003. Worker interests and male production in Polistes gallicus, a Mediterranean social wasp. Journal of Evolutionary Biology 16:254-259.

Sundström, L. 1994. Sex ratio bias, relatedness asymmetry and queen mating frequency in ants. Nature 367:266-268.

Sundström, L., M. Chapuisat, and L. Keller. 1996. Conditional manipulation of sex ratios by ant workers: a test of kin selection theory. Science 274:993-995.

Thompson, G. J., and B. P. Oldroyd. 2004. Evaluating alternative hypotheses for the origin of eusociality in corbiculate bees. Molecular Phylogenetics and Evolution 33:452-456.

Tóth, E., J. E. Strassmann, P. Nogueira-Neto, V. L. ImperatrizFonseca, and D. C. Queller. 2002b. Male production in stingless bees: variable outcomes of queen-worker conflict. Molecular Ecology 11:2661-2667.

Tóth, E., D. C. Queller, A. Dollin, and J. E. Strassmann. 2004. Conflict over male parentage in stingless bees. Insectes Sociaux 51:1-11.

Trivers, R. L., and H. Hare. 1976. Haplodiploidy and the evolution of the social insects. Science 191:249-263.

van Honk, C. 1982. The social structure of Bombus terrestris colonies: a review. Pages 196-200 in M. D. Breed, C. D. Michener, and H. E. Evans, eds. The biology of social insects. Westview, Boulder, CO.

Velthuis, H. H. W., D. d. A. Alves, V. L. Imperatriz-Fonseca, and M. J. Duchateau. 2002. Worker bees and the fate of their eggs. Proceedings of the Section Experimental and Applied Entomology of the Netherlands Entomological Society 13:97-102.

Velthuis, H. H. W., D. Koedam, and V. L. Imperatriz-Fonseca. 2005. The males of Melipona and other stingless bees, and their mothers. Apidologie 36:169-185.

Villesen, P., T. Murakami, T. R. Schultz, and J. J. Boomsma. 2002. Identifying the transition between single and multiple mating of queens in fungus-growing ants. Proceedings of the Royal Society B: Biological Sciences 269:1541-1548. 
Visscher, K. P., and R. Dukas. 1995. Honey bees recognize development of nestmates' ovaries. Animal Behaviour 49:542-544.

Walin, L., L. Sundström, P. Seppa, and R. Rosengren. 1998. Worker reproduction in ants: a genetic analysis. Heredity 81:604-612.

Wenseleers, T., and F. L. W. Ratnieks. 2004. Tragedy of the commons in Melipona bees. Proceedings of the Royal Society B: Biological Sciences 271:S310-S312.

2006. Enforced altruism in insect societies. Nature (forthcoming).

Wenseleers, T., F. L. W. Ratnieks, and J. Billen. 2003. Caste fate conflict in swarm-founding social Hymenoptera: an inclusive fitness analysis. Journal of Evolutionary Biology 16:647-658.

Wenseleers, T., A. G. Hart, and F. L. W. Ratnieks. 2004a. When resistance is useless: policing and the evolution of reproductive acquiescence in insect societies. American Naturalist 164:E154E167.

Wenseleers, T., H. Helanterä, A. G. Hart, and F. L. W. Ratnieks. $2004 b$.
Worker reproduction and policing in insect societies: an ESS analysis. Journal of Evolutionary Biology 17:1035-1047.

Wenseleers, T., N. S. Badcock, K. Erven, A. Tofilski, F. S. Nascimento, A. G. Hart, T. A. Burke, et al. 2005a. A test of worker policing theory in an advanced eusocial wasp, Vespula rufa. Evolution 59: 1306-1314.

Wenseleers, T., A. Tofilski, and F. L. W. Ratnieks. 2005b. Queen and worker policing in the tree wasp Dolichovespula sylvestris. Behavioral Ecology and Sociobiology 58:80-86.

Wilson, E. O. 2005. Kin selection as the key to altruism: its rise and fall. Social Research 72:159-166.

Woyciechowski, M., and A. Lomnicki. 1987. Multiple mating of queens and the sterility of workers among eusocial Hymenoptera. Journal of Theoretical Biology 128:317-327.

Associate Editors: Stuart A. West and Emília P. Martins Editor: Jonathan B. Losos 


\title{
Appendix from T. Wenseleers and F.L.W. Ratnieks, "Comparative Analysis of Worker Reproduction and Policing in Eusocial Hymenoptera Supports Relatedness Theory"
}

\author{
(Am. Nat., vol. 168, no. 5)
}

Table A1

Data on colony kin structure and the occurrence of queen and worker policing and worker dominance behavior in 48 species of eusocial Hymenoptera

\begin{tabular}{|c|c|c|c|c|c|c|c|c|c|}
\hline $\begin{array}{l}\text { TAXON } \\
\text { Species }\end{array}$ & $N_{e}$ & $r_{w-w}$ & $r_{\text {diff }}$ & Method & $\begin{array}{l}\text { Queen } \\
\text { policing }\end{array}$ & $\begin{array}{l}\text { Worker } \\
\text { policing }\end{array}$ & $\begin{array}{l}\text { Worker } \\
\text { dominance } \\
\text { behavior }\end{array}$ & $\begin{array}{l}\text { Aggression } \\
\text { or egg-eating? } \\
(\mathrm{A} / \mathrm{E})\end{array}$ & $\begin{array}{l}\text { Refs. for } \\
r_{w-w}\end{array}$ \\
\hline \multicolumn{10}{|l|}{ SWEAT BEES } \\
\hline Lasioglossum zephyrum & 1 & $0.75^{a}$ & 0.125 & A & yes & no & no & $\mathrm{A}+\mathrm{E}$ & 1 \\
\hline \multicolumn{10}{|l|}{ BUMBLEBEES } \\
\hline Bombus agrorum & 1 & $0.75^{\mathrm{a}}$ & 0.125 & - & yes & no ${ }^{b}$ & yes $^{b}$ & A & 2 \\
\hline Bombus ardens & 1 & $0.75^{\mathrm{a}}$ & 0.125 & - & yes & $?$ & yes & $\mathrm{A}+\mathrm{E}$ & 3 \\
\hline Bombus bifarius & 1 & $0.75^{\mathrm{a}}$ & 0.125 & $\mathrm{O}$ & $?$ & ? & yes & A & 4 \\
\hline Bombus ephippiatus & 1 & $0.75^{\mathrm{a}}$ & 0.125 & - & yes & $?$ & $?$ & $\mathrm{E}$ & 5 \\
\hline Bombus hypocrita & 1 & $0.75^{a}$ & 0.125 & - & yes & no ${ }^{b}$ & yes $^{b}$ & $\mathrm{~A}+\mathrm{E}$ & 6 \\
\hline Bombus impatiens & 1 & 0.67 & 0.085 & M & yes & no & no & $\mathrm{E}$ & 7 \\
\hline Bombus lapidarius & 1 & $0.75^{\mathrm{a}}$ & 0.125 & M & yes & no ${ }^{b}$ & yes $^{b}$ & $\mathrm{~A}+\mathrm{E}$ & 8 \\
\hline Bombus ruderatus & 1 & $0.75^{a}$ & 0.125 & - & yes & $?$ & $?$ & $A+E$ & 9 \\
\hline Bombus terrestris & 1 & $0.75^{\mathrm{a}}$ & 0.125 & M & yes & no ${ }^{b}$ & yes $^{b}$ & $A+E$ & 10 \\
\hline \multicolumn{10}{|l|}{ STINGLESS BEES } \\
\hline Melipona bicolor & 1.3 & 0.62 & 0.085 & M & yes & no & yes & $\mathrm{E}$ & 11 \\
\hline Melipona compressipes & 1 & $0.75^{\mathrm{a}}$ & 0.125 & - & yes & no & no & $\mathrm{E}$ & 12 \\
\hline Melipona favosa & 1 & $0.75^{\mathrm{a}}$ & 0.125 & - & $?$ & no & no & - & 13 \\
\hline Melipona scutellaris & 1 & $0.75^{\mathrm{a}}$ & 0.125 & M & yes & no & no & $\mathrm{E}$ & 14 \\
\hline Melipona subnitida & 1 & $0.75^{a}$ & 0.125 & A & $?$ & no & no & - & 15 \\
\hline Paratrigona subnuda & 1 & $0.75^{\mathrm{a}}$ & 0.125 & M & yes & no & no & $\mathrm{A}+\mathrm{E}$ & 16 \\
\hline Scaptotrigona depilis & 1 & $0.75^{\mathrm{a}}$ & 0.125 & - & yes & no & no & $\mathrm{E}$ & 17 \\
\hline Scaptotrigona postica & 1 & 0.73 & 0.115 & M & yes & no & no & $\mathrm{E}$ & 18 \\
\hline \multicolumn{10}{|l|}{ HONEYBEES } \\
\hline Apis cerana & 1 & 0.35 & -0.075 & M & $?^{\mathrm{c}}$ & yes $^{d}$ & no & $\mathrm{E}$ & 19 \\
\hline Apis florea & 1 & 0.29 & -0.105 & M & no & yes $^{\text {d }}$ & no & $\mathrm{E}$ & 20 \\
\hline Apis mellifera & 1 & 0.29 & -0.105 & M & $?^{\mathrm{c}}$ & yes $^{d}$ & no & $\mathrm{A}+\mathrm{E}$ & 21 \\
\hline Apis mellifera capensis ${ }^{\mathrm{e}}$ & 1 & $0.30^{\mathrm{a}}$ & $0^{\mathrm{e}}$ & M & $?^{\mathrm{c}}$ & yes $^{f}$ & no & $\mathrm{E}$ & 22 \\
\hline \multicolumn{10}{|l|}{ POLISTINAE WASPS } \\
\hline Polistes biglumis & 1 & $0.75^{\mathrm{a}}$ & 0.125 & - & $?$ & no & yes & $\mathrm{E}$ & 23 \\
\hline Polistes chinensis & 1 & $0.75^{\mathrm{a}}$ & 0.125 & $\mathrm{M}+\mathrm{A}$ & yes & no & yes & $\mathrm{E}$ & 24 \\
\hline Polistes dominulus & 1.4 & 0.56 & 0.072 & M & yes & no & yes & $\mathrm{E}$ & 25 \\
\hline \multicolumn{10}{|l|}{ VESPINAE WASPS } \\
\hline Dolichovespula arenaria & 1 & $0.71^{\mathrm{a}}$ & 0.104 & A & yes & $?$ & $?$ & $\mathrm{~A}+\mathrm{E}$ & 26 \\
\hline Dolichovespula media & 1 & 0.71 & 0.105 & M & yes & $?$ & $?$ & $\mathrm{E}$ & 27 \\
\hline Dolichovespula maculata & 1 & $0.75^{\mathrm{a}}$ & 0.125 & M & yes & no & yes & $\mathrm{A}+\mathrm{E}$ & 28 \\
\hline Dolichovespula norwegica & 1 & 0.71 & 0.105 & M & yes & no & yes & $A+E$ & 29 \\
\hline Dolichovespula saxonica & 1 & 0.62 & 0.060 & M & yes & ?g & $?$ & $\mathrm{~A}+\mathrm{E}$ & 30 \\
\hline Dolichovespula sylvestris & 1 & 0.68 & 0.090 & M & yes & no & yes & $A+E$ & 31 \\
\hline Vespa crabro gribodi & 1 & 0.67 & 0.085 & M & no & yes $^{d}$ & no & $\mathrm{E}$ & 32 \\
\hline Vespula germanica & 1 & 0.46 & -0.020 & M & no & yes $^{d}$ & no & $\mathrm{E}$ & 33 \\
\hline Vespula rufa & 1 & $0.58^{a}$ & 0.040 & M & yes & no & yes & $\mathrm{E}$ & 34 \\
\hline Vespula vulgaris & 1 & 0.51 & $0.005^{\mathrm{h}}$ & M & no & yes & no & $\mathrm{E}$ & 35 \\
\hline \multicolumn{10}{|l|}{ ANTS } \\
\hline Acromyrmex echinatior & 1 & 0.39 & -0.055 & M & $?^{\mathrm{c}}$ & yes $^{d}$ & no & $\mathrm{E}$ & 36 \\
\hline Aphaenogaster smythiesi & 1 & $0.75^{\mathrm{a}}$ & 0.125 & M & no & yes $^{d}$ & no & A & 37 \\
\hline Camponotus floridanus & 1 & $0.75^{\mathrm{a}}$ & 0.125 & $\mathrm{D}$ & $?^{\mathrm{c}}$ & yes $^{d}$ & no & $\mathrm{E}$ & 38 \\
\hline Crematogaster smithii & 1 & 0.71 & 0.105 & M & yes & no & no & $\mathrm{E}$ & 39 \\
\hline Diacamma sp. ${ }^{\mathrm{i}}$ & 1 & $0.75^{\mathrm{a}}$ & 0.125 & $\mathrm{O}$ & yes & yes & yes & $\mathrm{A}+\mathrm{E}$ & 40 \\
\hline Dinoponera quadriceps ${ }^{\mathrm{i}}$ & 1 & $0.75^{\mathrm{a}}$ & 0.125 & $\mathrm{O}$ & yes & no & yes & $\mathrm{A}+\mathrm{E}$ & 41 \\
\hline Formica fusca & 3.3 & 0.31 & $-0.0008^{h}$ & M & no & yes & no & $\mathrm{E}$ & 42 \\
\hline Harpagoxenus sublaevis & 1 & $0.75^{\mathrm{a}}$ & 0.125 & $\mathrm{~A}$ & yes & no & yes & A & 43 \\
\hline Leptothorax acervorum & 2.1 & 0.52 & 0.083 & $\mathrm{M}$ & yes & no & no & $\mathrm{E}$ & 44 \\
\hline Leptothorax unifasciatus & 1 & $0.75^{\mathrm{a}}$ & 0.125 & $\mathrm{~A}+\mathrm{M}$ & no & no & yes & A & 45 \\
\hline Pachycondyla inversa & 4.1 & 0.13 & -0.014 & M & no & yes & no & $\mathrm{E}$ & 46 \\
\hline Platythyrea punctata ${ }^{\mathrm{e}}$ & 1.1 & $1^{\mathrm{a}}$ & $0^{\mathrm{e}}$ & M & yes & yes $^{d}$ & no & A & 47 \\
\hline Protomognathus americanus & 1 & 0.68 & 0.090 & M & $?$ & no & yes & A & 48 \\
\hline
\end{tabular}


Note: Queen and worker policing are defined as the killing of worker-laid eggs or aggression towards reproductive workers by the queen or non-reproductive workers. Worker dominance behavior is defined as worker egg-eating or aggression associated with direct reproductive competition among egg-laying workers. Only policing and worker dominance behavior in queenright colonies are considered. Policing can occur via aggression (A) or egg-eating $(\mathrm{E})$ or both $(\mathrm{A}+\mathrm{E})$; $\mathrm{Ne}=$ effective number of queens; $\mathrm{rw} w$ woworker-worker relatedness; rdiff=difference in relatedness between workers' sons and queen's sons; Method=method used to estimate relatedness: $\mathrm{M}$ (microsatellites), A (allozymes), D (DNA fingerprinting), or O (pedigree relatedness, mating frequency determined through behavioral observation).

${ }^{a}$ Pedigree relatedness estimate; ${ }^{\mathrm{b}}$ Worker egg eating does occur but is not differential and is usually carried out by egg-laying workers (see notes below); ${ }^{\mathrm{c}}$ Presence of queen policing unknown since the queen did not have access to the eggs that were tested for survival; ${ }^{\mathrm{d}}$ Reproductive workers very rare in queenright colonies; worker-laid eggs most likely eaten by nonreproductive workers; ${ }^{\mathrm{e}}$ Workers produce diploid female offspring through thelytokous parthenogenesis (Anderson 1963; Heinze and Hölldobler 1995; Schilder et al. 1999a,b). Since the relatedness to the worker's daughters is the same as to the mother's daughters (sisters), $r_{\text {diff }}=0 ;{ }^{\mathrm{f}}$ In some colonies of $A$. mellifera capensis, worker policing has been shown to be absent (Beekman et al. 2002) and policing is generally less effective than in $A$. mellifera mellifera/ligustica (Pirk et al. 2003); ${ }^{\mathrm{g}}$ Genetic analysis suggests that worker policing is present in multiple paternity colonies, but this remains to be demonstrated by direct behavioral observation (Foster and Ratnieks 2000); ${ }^{\mathrm{h}} r_{\text {diff }}$ is not significantly different from zero; ${ }^{\text {i }}$ Colonies are headed by a single mated worker or 'gamergate' (Monnin and Ratnieks 2001).

References for relatedness estimates: 1, 10, 14-16, 18-21, 24, 26-36, 39, 41-45 and 48: see Table A2; 2, 3, 5, 6, 9, 12, 13, 17 and 23: Formal relatedness estimate not available, but single mating is the rule in bumblebees, stingless bees and polistine wasps (Peters et al. 1999; Schmid-Hempel and Schmid-Hempel 2000; Strassmann 2001). In bumblebees, a male mating plug also prevents queens in some species from mating multiply (Baer et al. 2001). In addition, putative evidence for multiple mating in a few species of stingless bees has been overturned and has since been shown to be due to the accidental inclusion of drifted workers (Paxton et al. 2001a; Palmer et al. 2002); 4 Hobbs 1967; 7 Cnaani et al. 2002; 8 Schmid-Hempel and Schmid-Hempel 2000; 11 Peters et al. 1999; Effective number of queens and $r_{\text {diff }}$ were calculated from the worker-worker relatedness, assuming that queens are related by $0.5 ; 22$ Moritz et al. 1999; 25 The relatedness among gynes in the fall is $r=0.56$ (Queller et al. 2000) and the average relatedness among foundresses is $G=0.44$ (Queller et al. 2000). From the formula $r=\left(3+G .\left(N_{e}-1\right)\right) / 4 N_{e}$, the mean effective number of queens can be estimated at $N_{e}=1.4$. The difference in relatedness between workers' sons and queen's sons $r_{d i f f}=r_{w-w m}-r_{w-q m}=r_{w-w} / 2-\left(1+G\left(N_{e}-1\right)\right) / 4 N_{e}=0.072$ (Pamilo 1991). 37 Iwanishi et al. 2003; 38 Gadau et al. 1996; 40 Kikuta and Tsuji 1999; Gamergates are single mated, since after mating, the genitals of the male and part of its abdomen remain attached to the female. This acts as a mating plug and prevents further matings; 46 Nest are usually polygynous and microsatellite analysis has shown that the relatedness among queens $G=0.097$ (Kolmer et al. 2002) and that queens are multiple mated (harmonic mean paternity $k=2.4$, K. Kellner, A. Trindl, J. Heinze and P. D'Ettorre, pers. comm.). In the most recent and extensive study, workerworker relatedness has been measured at $r_{w-w}=0.13$ (K. Kellner, A. Trindl, J. Heinze and P. D'Ettorre, pers. comm.). From the formula $r_{w-w}=(2+k) /\left(4 k N_{e}\right)$, the mean effective number of queens can be estimated at 4.1. Using these parameters, $r_{d i f f}=r_{w-w m}-r_{w-q m}=r_{w-w} / 2-\left(1+G\left(N_{e^{-}}\right.\right.$ 1)) $/ 4 N_{e}=-0.014$ (Pamilo 1991); 47 Schilder et al. 1999a

Notes with evidence used to infer presence or absence of policing: SWEAT BEES: L. zephyrum. Queens aggress workers with active ovaries and eat worker-laid eggs (Michener and Brothers 1974, also see Batra 1968 and Buckle 1982). Workers do not usually kill eggs, so there is no evidence for worker policing or worker dominance behavior. BUMBLEBEES: B. agrorum. A single reproductive worker was observed to be repeatedly attacked by the queen (Brian 1951). The reproductive worker eventually succeeded in laying a few eggs. Reproductive workers also show dominance behavior to each other (Free 1955, also see Brian 1952). Egg-eating by the queen or workers was not observed (Brian 1951). B. ardens. The queen aggressed workers that attempted to kill her eggs and also aggressed egg-laying workers and ate worker-laid eggs (Katayama 1997). Workers were also observed eating worker-laid eggs. This was probably linked to direct competition over egg-laying since 3 out of 13 workers who were seen to eat eggs later laid eggs themselves (Katayama 1997). The data are insufficient to determine whether worker policing by non-reproductive workers occurs, or whether all egg eating is by egglaying workers. The data show clearly that some egg-eating was by egg-laying workers. B. bifarius. Workers with active ovaries show mutual aggression (Foster et al. 2004). No data on worker egg-laying or the fate of worker-laid eggs were presented. B. ephippiatus. The queen has been observed to eat worker-laid eggs (J.I. Cuadriello-Aguilar, pers. comm.). B. hypocrita. Laying workers kill the queen's eggs and other workers' eggs, and replace them by their own (Katayama 1974). Egg laying workers are also aggressive towards one another. The queen was mildly aggressive towards egg-laying workers and sometimes pushed them off their cell to prevent them from laying eggs. However, she was not observed to eat any worker-laid eggs and in a few cases just added her own eggs to the workers' batch of eggs (Katayama 1974). Hence, this species has worker dominance behavior, and a mild form of queen policing. B. impatiens. One worker was seen to lay a batch of eggs, but the eggs were all eaten by the queen (Cnaani et al. 2002). The reproductive worker was also aggressive towards the queen (Cnaani et al. 2002). No worker-worker aggression occurred in queenright colonies and worker oophagy was not reported. B. lapidarius. Hoffer (1882-83), Lindhard (1912) and Plath (1923) showed that the queen aggresses egg-laying workers and eats worker-laid eggs. Free et al. (1969) also reported that the queen attacks workers with active ovaries and workers that attempt to build their own egg cups, and that she frequently kills worker-laid eggs. In addition, workers sometimes attempted to open existing egg cups, and steal eggs from them, although the queen defended her eggs vigorously to prevent them from being eaten (Free et al. 1969). Workers with active ovaries also aggressed other workers to maintain their dominance position; workers with active ovaries, however, were not aggressed by other workers. B. ruderatus. Queens have been observed to eat worker-laid eggs (Pomeroy 1979). However, no details on worker oophagy or aggression were given, so we consider it uncertain whether worker policing or worker dominance behavior might also occur. B. terrestris. Worker egg-laying is common near the end of season (Sladen 1912; Cumber 1949; Free and Butler 1959; Röseler and Honk 1990; Bloch and Hefetz 1999). However, the queen aggresses egg-laying workers (Röseler and van Honk 1990) and the majority of the worker-laid eggs are eaten by the queen and by other egg-laying workers (Duchateau 1989, 1996; Velthuis et al. 2002). Workers often destroy queen-laid eggs and then replace them by their own (van Honk and Hogeweg 1981; van Honk et al. 1981; Duchateau and Velthuis 1988; Bloch and Hefetz 1999). Aggression among egg-laying workers is also common (Van Doorn 1987; Duchateau 1989). STINGLESS BEES: M. bicolor. Workers lay reproductive eggs, but competing reproductive workers frequently eat and replace these by their own eggs (Velthuis et al. 2002; Koedam et al. 2006). The queen also eats worker-laid egg. Although these eggs were initially thought to have a purely trophic function, they are in fact viable (Koedam et al. 2001). Hence, both worker dominance behavior and queen policing occur. M. compressipes. Workers lay eggs of similar form to queen-laid eggs, presumably indicating that they are reproductive and viable (Sakagami and Oniki 1963). All 18 eggs laid by workers, however, were observed to be eaten by the queen. In any one cell, up to 6 workers successively oviposited, but after each worker oviposition, the queen ate the worker-laid egg. Eventually, all cells contained queen-laid eggs. M. favosa. Worker production of males is widespread, with $94.5 \%$ of all adult males being workers' sons (Sommeijer et al. 1999; Chinh et al. 2003). Eggs laid by workers are never eaten by other workers, implying that worker policing is absent (Chinh et al. 2003). The eating of worker-laid eggs by the queen is also common, but most of these eggs are thought to be trophic and 
non-viable. M. scutellaris. Sommeijer et al. (1984) observed that a worker who had just laid a reproductive egg and was in the process of sealing the cell was pushed aside by the queen. The queen then reopened the cell, ate the worker-laid egg and mounted the cell for egglaying. In that particular instance, however, the queen's oviposition attempt failed as she was pushed aside by another reproductive worker before she could lay her egg. M. subnitida. Worker production of males is widespread, with c. $36 \%$ of the adult males being workers' sons (Koedam et al. 1999, 2005, Table A2). Eggs laid by workers are never eaten by other workers, implying that worker policing is absent (Koedam et al. 1999, 2005). The eating of worker-laid eggs by the queen is also common, but most of these eggs are thought to be trophic and non-viable. P. subnuda. Worker production of males is widespread in this species, with $64 \%$ of the males being workers' sons (Tóth et al. 2002a). Worker reproduction proceeds in an unusual way. Workers reopen sealed cells and drop in reproductive eggs through a small hole in the cell (Tóth et al. 2002a). The queen also sometimes aggresses workers while they are doing this. This implies the presence of a form of queen policing. Nevertheless, the strategy of reopening cells evidently makes it much harder for the queen to effectively police the workers. Workers never interfere with other egg-laying workers. Workers also lay eggs in approximately one in four cells before cells are sealed, and these eggs are always eaten by the queen. It is unknown, however, whether these eggs are viable. $\boldsymbol{S}$. depilis. da Silva et al. (2001) showed that workers lay both trophic and reproductive eggs. The trophic eggs could be distinguished by their more flaccid and rounder appearance. The queen, however, always ate both types of eggs, before laying her own egg. S. postica. As in S. depilis, workers in this species were found to lay both trophic and reproductive eggs (Bego 1990). Workers were observed to lay 118 trophic and 73 reproductive eggs. Out of the 73 reproductive eggs, however, 69 were eaten by the queen (Bego 1990). This implies that the queen policed worker reproduction through the eating of the workers' eggs. Competition among egg-laying workers sometimes resulted in up to 5 eggs being laid in a single cell. Workers were also found to lay more eggs when the colony was in a male producing period, that is, when the queen was laying haploid eggs. This would reduce the cost of worker reproduction as workers' sons would be traded off against queen's sons and not against new workers, who are part of colony female reproduction via swarm production. HONEYBEES: A. cerana. Worker-laid eggs from queenless nests are preferentially removed compared to queen-laid eggs when introduced into queenright discriminator colonies (Oldroyd et al. 2001). In the experiments performed, queens had access to the eggs that were tested for survival. Hence, although most of the eggs are probably killed by the workers, it cannot presently be excluded that the queen also polices some of the worker-laid eggs. A. florea. Worker-laid eggs from queenless nests are preferentially removed when introduced into queenright colonies (Halling et al. 2001). In the experiments performed, queens had access to the eggs that were tested for survival. Nevertheless, queen policing was inferred to be absent, since during the experiments, the queen was not observed on the introduced drone comb. By contrast, workers were observed inserting their heads into cells, removing eggs, and eating them on several occasions. A. mellifera. In three races of Apis mellifera, A. mellifera mellifera, A. mellifera ligustica and A. mellifera scutellata, it has been shown that worker-laid eggs from queenless nests are preferentially removed when introduced into queenright colonies (A. m. m., A. m. ligustica or hybrid: Ratnieks and Visscher 1989; Ratnieks 1995; Visscher 1996; Katzav-Gozansky et al. 2001; Miller and Ratnieks 2001; Martin et al. 2002b, 2005; Halling and Oldroyd 2003; Beekman et al. 2004; Beekman and Oldroyd 2005; A. m. scutellata: Beekman et al. 2002; Martin et al. 2002a; Neumann et al. 2003; Pirk et al. 2003). In all these experiments, the queen was denied access to the eggs under test by using a queen excluder. Hence, all the observed policing was carried out by workers. At present, it is unknown whether queens ever police worker-laid eggs. Velthuis et al. (2002) and Pirk et al. (2004) suggested that worker-laid eggs have lower viability than queenlaid ones, and that workers merely police dead eggs. This idea, however, has since been disproven (Beekman and Oldroyd 2005). Ratnieks (1993) showed that eggs that are naturally laid by workers in queenright colonies are also quickly removed. Finally, it has been shown that reproductive workers from queenless colonies are aggressed by other workers when introduced into queenright colonies (Visscher and Dukas 1995; Dampney et al. 2002). A. mellifera capensis. In the Cape honeybee, workers can produce diploid female offspring through thelytokous parthenogenesis (Anderson 1963). Since the relatedness to sister workers' daughters is the same as to the mother's daughters (sisters), $r_{d i f f}=0$, and worker policing should not be selected for on relatedness grounds (Greeff 1996). Genetic analysis has shown that unpoliced worker-laid brood indeed is common in this species (Moritz et al. 1999). Beekman et al. (2002) also showed that out of three colonies of mixed A. mellifera scutellata and A. mellifera capensis race, introduced worker-laid eggs were not differentially policed in the colony where workers were most capensis-like, but were in the two other where workers were more scutellata-like. Pirk et al. (2003), by contrast, concluded that introduced worker-laid eggs were differentially policed in A. m. capensis. Nevertheless, the policing was much less effective than in A. mellifera mellifera (ca. 50\% effective in A. m. capensis vs. $98 \%$ effective in A. m. mellifera). On relatedness grounds, a low level of worker policing may also remain to be selected for if workers not only produce female but also male eggs. Genetic analysis has shown that this can be the case (Moritz et al. 1999), particularly in colonies of mixed A. mellifera capensis and A. $m$. scutellata race. In our analysis, however, we assumed that workers only produce female offspring and hence that $r_{d i f f}=0$. Microsatellite analysis of one capensis colony showed that the effective queen mating frequency was 10.1, giving $r_{w-w}=0.30$ (Moritz et al. 1999). POLISTINAE WASPS: P. biglumis. Yamane (pers. comm.), cited in Miyano (1983), mentions that egg-laying workers in this species compete for reproduction by eating each other's eggs. P. chinensis. Both the queen and the workers remove worker-laid eggs (Saigo and Tsuchida 2004). However, when workers eat each others' eggs they always immediately replace the killed egg by one of their own. The percentage of eggs that are worker-laid can be very high, sometimes approaching 100\% (Miyano 1983; Tsuchida et al. 2003; Saigo and Tsuchida 2004). P. dominulus. In this species, the queen polices worker-laid eggs and workers also replace other workers' eggs with their own eggs (Liebig et al. 2005). Vespinae WASPS: D. arenaria. The queen commonly eats worker-laid eggs (Greene et al. 1976; Greene 1979). It has also been observed that ovipositing workers may be chased over the comb by the queen and that they may be vigorously mauled by her if caught (Greene 1979). D. media. Foster et al. (2001) mention that the queen may police worker-laid eggs. D. maculata. The queen commonly eats worker-laid eggs and may aggress egg-laying workers (Greene 1979). D. norwegica. Worker-laid eggs are removed both by the queen and by other competing egg-laying workers (T. Wenseleers, A. Tofilski, F.S. Nascimento, K. Vuerinckx and F.L.W. Ratnieks, unpublished data). The queen may also aggress workers with active ovaries. In addition, aggression among egg-laying workers is common. D. saxonica. Foster et al. (2001) mention that the queen may police worker-laid eggs. Genetic analysis also suggests that worker policing is facultatively expressed in multiple paternity colonies (Foster and Ratnieks 2000). However, this remains to be confirmed by direct behavioral observation. $\boldsymbol{D}$. sylvestris. An initial study showed that worker-laid eggs were removed both by the queen and by other workers (Wenseleers et al. 2005b). However, a later analysis showed that $95 \%$ of the eggs eaten by workers were removed by workers who themselves laid eggs (T. Wenseleers, A. Tofilski, F.S. Nascimento, K. Erven and F.L.W. Ratnieks, unpublished manuscript). Hence, the worker egg-eating is caused by direct reproductive competition and is not genuine worker policing. The queen may also aggress egg-laying workers and reproductive workers frequently fight each other. V. crabro gribodi. Worker-laid eggs from queenless nests are differentially removed when introduced into queenright colonies (Foster et al. 2002). Since the queen did not visit the comb with introduced eggs during the larger part of the trials, queen policing was probably absent. Since only c. $2 \%$ of the workers had active ovaries in queenright colonies (Foster et al. 2000), most policing was probably carried out by non-reproductive workers. V. germanica. Worker-laid eggs from queenless nests are differentially removed when introduced into queenright colonies (T. Wenseleers, R.L. Hammond, K. Vuerinckx, J. Billen and L. Keller, unpublished data). Since the queen did not visit the comb with introduced eggs during the larger part of the trials, queen policing was probably absent. Since only c. 1.5\% of the workers had active ovaries in queenright 
colonies, most policing was probably carried out by non-reproductive workers. $V$. rufa. In queenright colonies, $12 \%$ (28/232) of the eggs were laid by workers (Wenseleers et al. 2005a). Out of the 28 eggs laid by workers, 11 were eaten by the queen and 8 were eaten by workers. The remaining 9 eggs were not eaten (Wenseleers et al. 2005a). In 2 out of the 8 cases where a worker removed a worker-laid egg, the policing worker laid an egg soon after (Table S1, Ratnieks et al. 2006). For the remaining 6 cases it was not known whether the policing workers had active ovaries or not. Overall, these results show that most of the policing was by the queen and that egg eating by workers probably reflected direct reproductive competition rather than true worker policing. $\boldsymbol{V}$. vulgaris. Worker-laid eggs from queenless nests are differentially removed when introduced into queenright colonies (Foster and Ratnieks 2001a). Experiments have shown that the workers who police do not have active ovaries (T. Wenseleers and A. Tofilski, unpublished data). Since the queen did not visit the comb with introduced eggs during the larger part of the trials, queen policing was probably absent (Foster and Ratnieks 2001a). It has also been shown that worker-laid eggs have a similar viability as queen-laid ones (Helanterä et al. 2006), thereby eliminating the possibility that workers might police for hygienic reasons (Pirk et al. 2004). ANTS: A. echinatior. Worker-laid eggs collected from queenless colonies were differentially removed by workers when introduced into queenright nests (Dijkstra and Boomsma 2004). Worker-laid eggs were removed by non-reproductive workers, since all workers in queenright nests are effectively sterile (Dijkstra et al. 2005). The presence or absence of queen policing could not be studied. A. smythiesi. Reproductive workers from queenless colonies were preferentially aggressed when introduced into queenright nests (Iwanishi et al. 2003). The attacking workers were non-reproductive, since workers in queenright nests never have fully developed ovaries (Iwanishi and Ohkawara 2005) and are thought to only lay unviable, trophic eggs (Iwanishi et al. 2003). The eggs laid by workers from queenless colony fragments were seen to be eaten by other workers and by the queen. It is unknown, however, whether this egg-eating was differential, and whether it represented genuine queen or worker policing. C. floridanus. Worker-laid eggs collected from queenless colonies were differentially removed by workers when introduced into nests from which the queen was temporarily removed (Endler et al. 2004). Worker-laid eggs were almost certainly removed by nonreproductive workers, since workers in queenright nests do not lay eggs (Endler et al. 2004). The occurrence of queen policing could not been studied due to the experimental design that was used, whereby the queen was temporarily removed. C. smithii. This species has a subcaste of large workers morphologically specialized to lay unfertilized eggs (Heinze et al. 1999). Because many of these worker-laid eggs were eaten by the queen, these eggs were initially thought to have a purely trophic function (Heinze et al. 1999). However, a later genetic study (Heinze et al. 2000) showed that a significant percentage of the adult males (11\%, Table A2) were workers' sons, implying that many of the eggs were in fact viable. Hence, egg eating by the queen is probably best interpreted as queen policing. Workers were not seen to consume eggs laid by other workers. Diacamma sp. In this species colonies are headed by a single queen (who is actually a mated worker or 'gamergate') (Nakata and Tsuji 1996; Kikuta and Tsuji 1999). Studies on the occurrence of queen and worker policing are slightly conflicting. On the one hand, Nakata and Tsuji (1996) reported that in natural queenright colonies there is only queen policing and some worker dominance behavior, but no genuine worker policing. The fate of 9 eggs laid by workers could be followed, and 8 of these were eaten by the gamergate; the remaining egg was added to the egg-pile. Workers in natural queenright colonies were never observed to consume any eggs (Nakata 1995). Aggressive interactions were common, but mostly restricted to dominant, egg-laying workers. Using an alternative approach, whereby reproductive workers from orphaned nests were introduced into queenright colonies, Kikuta and Tsuji (1999) confirmed that the majority (89\%) of the worker-laid eggs are eaten and that most of the egg-policing was by the gamergate $(60 / 89=67 \%$ of the eggs killed). However, the remainder of the eggs were eaten by workers. Kikuta and Tsuji (1999) show that although some of the policing workers likely had active ovaries (especially when the policing was by workers from the orphaned colony fragment), $32 \%$ of the worker policing was by workers from the gamergate-right colony fragment, none of whom had active ovaries. Hence, the Kikuta and Tsuji (1999) study shows that there was a mixture of queen policing, worker dominance behavior and genuine worker policing. Finally, a third study by Kawabata and Tsuji (2005) showed that reproductive workers from orphaned nests are also attacked by non-reproductive workers when introduced into gamergate-right colonies. This implies that worker policing also occurs through aggression. In our analysis, we therefore scored worker policing as being present, although the above discussion shows that in natural colonies, this behavior may actually be rare. D. quadriceps. In this species colonies are also headed by a mated worker or 'gamergate' (Monnin and Peeters 1997). 12 out of 18 worker-laid eggs were policed by the queen (Monnin and Peeters 1997). One gamergatelaid and one worker-laid egg was also eaten by a subordinate worker, but since this type of egg-cannibalism was very rare and nondifferential, it does not represent genuine worker policing. The top-ranking unmated egg-layers also show aggressive interactions towards workers of lower rank (Monnin and Ratnieks 2001). Hence, there is also worker dominance behavior. F. fusca. Egg-introduction experiments showed that worker-laid eggs were policed by workers but not by queens (Helanterä and Sundström 2005). H. sublaevis. Workers in queenright colonies lay eggs and reproductive workers engage in dominance interactions (Bourke 1988a). The queen also aggresses reproductive workers (Bourke 1988a). Egg cannibalism by non-reproductive workers is thought to be absent. An allozyme study was unable to demonstrate any adult worker-produced males (Bourke et al. 1988). Nevertheless, this may be due to a lack of power (number of assignable males=29, Table A2). L. acervorum. Bourke (1991) reported that 4 out of 16 reproductive worker-laid eggs were eaten by queens. In addition, the queens consumed 2 non-viable, trophic eggs laid by workers. It was further shown that the eating of intact eggs was unique to queens and that workers never ate undamaged eggs. Although these observations of egg eating were from polygynous nests, in which the queens also consumed eggs laid by other queens (Bourke 1991), it seems that the egg eating was discriminatory, and hence represents genuine queen policing. Evidence for differential eating of worker-laid eggs comes from a comparison of the percentage of male eggs and adults that are workers' sons. Based on the data in Bourke (1991) and assuming the queen laid male and female eggs in an equal ratio, $12.4 \%$ of the male eggs can be inferred to be worker-laid. By contrast, a microsatellite study showed that only $2.8 \%$ of the adult males are workers' sons (Hammond et al. 2003). This suggests that some of the worker-laid eggs are differentially removed. On the other hand, in a genetic study, Hammond et al. (2003) found no difference between the proportion of male eggs and adults that were workers' sons. Nevertheless, as acknowledged in that study, this may have been because the eggs that were genotyped likely contained a bias of older eggs, so that the actual percentage of newly-laid male eggs that were workers' sons would have been underestimated. Worker-worker aggression has also been noted in this species, although it could not be clearly connected to conflict over egg-laying (Bourke 1991). L. unifasciatus. Queen and worker policing was absent, since worker-laid eggs from orphaned nests were not differentially removed by either the queen or the workers when introduced into queenright colonies (N. Stroeymeyt, E. Brunner and J. Heinze, pers. comm.). Egg-laying workers, however, received targeted aggression from other workers who later become dominant and started laying eggs. Hence, worker dominance behavior does occur. P. inversa. Worker-laid eggs collected from orphaned nests were differentially removed when introduced into queenright colonies (D'Ettorre et al. 2004). P. punctata. In this species, workers produce diploid females from unfertilized eggs by thelytokous parthenogenesis, which results in a clonal colony structure (Heinze and Hölldobler 1995; Schilder et al. 1999a,b). All individuals are morphologically identical and equally capable of laying eggs, but each colony nevertheless contains only one, or rarely two, egg-layers (Schilder et al. 1999b). When additional reproductive workers from orphaned nests are added to colonies they are attacked by other workers (Hartmann et al. 2003), and, when the introduced reproductive workers are older than 2 months, also by the resident reproductive (Hartmann et al. 2005). P. americanus. Workers in queenright colonies lay eggs and reproductive workers engage in dominance interactions (Heinze 1996). A microsatellite analysis showed that a large percentage, $41 \%$, of the adult males are workers' sons (Foitzik and Herbers 2001, Table A2), indicating that worker-laid eggs are not policed. 
Table A2

Data on colony kin structure and male parentage in 90 species of eusocial Hymenoptera

\begin{tabular}{|c|c|c|c|c|c|c|c|c|c|c|c|}
\hline $\begin{array}{l}\text { TAXON } \\
\text { Species }\end{array}$ & $\begin{array}{l}\text { Colony class } \\
\text { or study }\end{array}$ & $N_{e}$ & $r_{w-w}$ & $r_{\text {diff }}$ & $W P M$ & $n_{c}$ & $n_{m}$ & $n_{a}$ & Met & $S I V$ & Refs. \\
\hline \multicolumn{12}{|l|}{ SWEAT BEES } \\
\hline Augochlorella striata $\left({ }^{*}\right)$ & (eusocial cols.) & 1 & $0.75^{\mathrm{a}}$ & 0.125 & 0.0 & 12 & 49 & 28.4 & $\mathrm{D}$ & NS & 1 \\
\hline Lasioglossum laevissimum $\left({ }^{*}\right)$ & & 1 & $0.75^{\mathrm{a}}$ & 0.125 & 52.0 & 83 & 108 & 54 & A & & 2 \\
\hline Lasioglossum malachurum $(*)$ & & 1.1 & 0.74 & 0.120 & 4.7 & 7 & 80 & 63.8 & M & & 3 \\
\hline Lasioglossum zephyrum $\left.{ }^{*}\right)$ & & 1 & $0.75^{\mathrm{a}}$ & 0.125 & 15.0 & 14 & 176 & 88 & A & & 4 \\
\hline \multicolumn{12}{|l|}{ BUMBLEBEES } \\
\hline Bombus hypnorum & LP, study 1 & 1 & 0.65 & 0.075 & 0.0 & 7 & 162 & 81 & $\mathrm{M}$ & & 5 \\
\hline Bombus hypnorum & LP, study 2 & 1 & $0.75^{\mathrm{a}}$ & 0.125 & 18.5 & 10 & 1,193 & 595.5 & M & & 6 \\
\hline Bombus hypnorum & LP, comb. est. & 1 & 0.71 & 0.105 & 16.4 & 17 & 1,355 & 676.5 & M & $N S^{\mathrm{d}}$ & \\
\hline Bombus hypnorum & $\mathrm{HP}$ & 1 & 0.48 & -0.010 & 0.0 & 1 & 71 & 35.5 & M & & 5 \\
\hline Bombus hypnorum & all & 1 & 0.69 & 0.095 & 15.4 & 28 & 1,426 & 712 & M & & \\
\hline Bombus melanopygus $\left(^{*}\right)$ & & 1 & $0.75^{\mathrm{a}}$ & 0.125 & 19.1 & 15 & 1,125 & $562.5^{\mathrm{b}}$ & $\mathrm{P}$ & & 7 \\
\hline Bombus terrestris $\left(^{*}\right)$ & study 1 & 1 & $0.75^{\mathrm{a}}$ & 0.125 & $3.8^{\mathrm{c}}$ & 32 & 1,501 & $1,357.4$ & M & & 8 \\
\hline Bombus terrestris $\left({ }^{\star}\right)$ & study 2 & 1 & $0.75^{\mathrm{a}}$ & 0.125 & 4.8 & 10 & 395 & 395 & M & & 9 \\
\hline Bombus terrestris $\left(^{*}\right)$ & study 3 & 1 & $0.75^{\mathrm{a}}$ & 0.125 & 2.3 & 5 & 1,853 & $926.5^{\mathrm{b}}$ & $\mathrm{P}$ & & 10 \\
\hline Bombus terrestris $\left(^{*}\right)$ & combined est. & 1 & $0.75^{\mathrm{a}}$ & 0.125 & 3.4 & 47 & 3,749 & $2,678.9$ & $\mathrm{M}+\mathrm{P}$ & & \\
\hline \multicolumn{12}{|l|}{ STINGLESS BEES } \\
\hline Austroplebeia australis & & 1 & $0.75^{\mathrm{a}}$ & 0.125 & 7.0 & 1 & 94 & 70.5 & M & & 11 \\
\hline Austroplebeia symei & & 1 & $0.75^{\mathrm{a}}$ & 0.125 & 5.0 & 4 & 130 & 65 & M & & 12 \\
\hline Melipona beecheii $\left(^{*}\right)$ & & 1 & $0.75^{\mathrm{a}}$ & 0.125 & 0.0 & 13 & 108 & $54^{\mathrm{b}}$ & M & & 13 \\
\hline Melipona favosa $\left(^{*}\right)$ & & 1 & $0.75^{\mathrm{a}}$ & 0.125 & 94.5 & 4 & 604 & 604 & B & & 14 \\
\hline Melipona marginata & & 1 & $0.75^{\mathrm{a}}$ & 0.125 & 37.1 & 3 & 41 & $20.5^{b}$ & M & & 15 \\
\hline Melipona quadrifasciata & & 1 & $0.75^{\mathrm{a}}$ & 0.125 & 64.2 & 2 & 47 & $23.5^{b}$ & M & & 15 \\
\hline Melipona scutellaris & & 1 & $0.75^{\mathrm{a}}$ & 0.125 & 28.3 & 5 & 46 & $23^{b}$ & M & & 15 \\
\hline Melipona subnitida $\left(^{*}\right)$ & study 1 & 1 & $0.75^{\mathrm{a}}$ & 0.125 & 39.3 & 17 & 300 & $150^{\mathrm{b}}$ & A & & 16 \\
\hline Melipona subnitida $\left.{ }^{*}\right)$ & study 2 & 1 & $0.75^{\mathrm{a}}$ & 0.125 & 33.6 & 3 & 292 & 292 & $\mathrm{~B}$ & & 17 \\
\hline Melipona subnitida ${ }^{*}$ ) & combined est. & 1 & $0.75^{\mathrm{a}}$ & 0.125 & 36.3 & 20 & 592 & 442 & $A+B$ & & 18 \\
\hline Paratrigona subnuda & & 1 & $0.75^{\mathrm{a}}$ & 0.125 & 64.0 & 6 & 418 & $209^{\mathrm{b}}$ & $\mathrm{M}$ & & 18 \\
\hline Plebeia droryana & study 1 & 1 & $0.75^{\mathrm{a}}$ & 0.125 & 0.0 & 1 & 19 & $9.5^{\mathrm{b}}$ & M & & 15 \\
\hline Plebeia droryana $\left({ }^{* *}\right)$ & study 2 & 1 & $0.75^{\mathrm{a}}$ & 0.125 & 16.2 & 14 & 281 & $140.5^{\mathrm{b}}$ & A & & 19 \\
\hline Plebeia droryana $\left({ }^{* *}\right)$ & combined est. & 1 & $0.75^{\mathrm{a}}$ & 0.125 & 15.2 & 15 & 300 & 150 & $\mathrm{M}+\mathrm{A}$ & & \\
\hline Plebeia remota & & 1 & $0.75^{\mathrm{a}}$ & 0.125 & 2.4 & 5 & 83 & $41.5^{\mathrm{b}}$ & $\mathrm{M}$ & & 15 \\
\hline Plebeia saiqui & & 1 & $0.75^{\mathrm{a}}$ & 0.125 & 0.0 & 3 & 66 & $33^{\mathrm{b}}$ & M & & 15 \\
\hline Scaptotrigona postica & study 1 & 1 & 0.72 & 0.109 & 13.1 & 8 & 160 & 144.6 & M & & 20 \\
\hline Scaptotrigona postica & study 2 & 1 & $0.75^{\mathrm{a}}$ & 0.125 & 18.5 & 3 & 62 & $31^{\mathrm{b}}$ & M & & 15 \\
\hline Scaptotrigona postica & combined est. & 1 & 0.73 & 0.115 & 14.7 & & 222 & $111^{b}$ & M & & \\
\hline Schwarziana quadripunctata & & 1 & $0.75^{\mathrm{a}}$ & 0.125 & 0.0 & 16 & 314 & $157^{\mathrm{b}}$ & M & & 21 \\
\hline Tetragona clavipes & & 1 & $0.75^{\mathrm{a}}$ & 0.125 & 65.0 & 5 & 47 & $23.5^{\mathrm{b}}$ & M & & 15 \\
\hline Trigona carbonaria & & 1 & $0.75^{\mathrm{a}}$ & 0.125 & 0.0 & 1 & 20 & 10 & M & & 22 \\
\hline Trigona clypearis & & 1 & $0.75^{\mathrm{a}}$ & 0.125 & 0.0 & 4 & 46 & 42 & M & & 23 \\
\hline Trigona hockingsi & & 1 & $0.75^{\mathrm{a}}$ & 0.125 & 0.0 & 4 & 79 & 33 & M & & 23 \\
\hline Trigona mellipes & & 1 & $0.75^{\mathrm{a}}$ & 0.125 & 0.0 & 4 & 42 & 23 & M & & 23 \\
\hline \multicolumn{12}{|l|}{ HONEYBEES } \\
\hline Apis cerana & & 1 & 0.35 & -0.075 & 0.0 & 5 & 652 & 365 & M & & 24 \\
\hline Apis dorsata & & 1 & 0.29 & -0.105 & 0.0 & 4 & 660 & 521 & M & & 25 \\
\hline Apis florea & & 1 & 0.29 & -0.105 & 0.0 & 4 & 564 & 269 & M & & 26 \\
\hline Apis mellifera $\left({ }^{*}\right)$ & & 1 & 0.29 & -0.105 & 0.1 & 11 & 57,960 & 28,980 & $\mathrm{P}$ & & 27 \\
\hline \multicolumn{12}{|l|}{ SPHECID WASPS } \\
\hline Microstigmus comes $\left.{ }^{*}\right)$ & & 1 & 0.67 & 0.085 & 0.0 & 21 & 63 & 31.5 & A & & 28 \\
\hline \multicolumn{12}{|l|}{ POLISTINAE WASPS } \\
\hline Brachygastra mellifica $\left.{ }^{* *}\right)$ & & 398 & 0.23 & -0.135 & 0.0 & 4 & 60 & $30^{\mathrm{b}}$ & M & & 29 \\
\hline Parachartergus colobopterus $\left({ }^{* *}\right)$ & & 45.8 & 0.19 & -0.155 & 0.0 & 5 & 200 & $100^{\mathrm{b}}$ & M & & 30 \\
\hline Polybioides tabidus $\left.{ }^{* *}\right)$ & & 34 & 0.20 & -0.150 & 2.0 & 5 & 247 & $123.5^{\mathrm{b}}$ & M & & 31 \\
\hline Polistes bellicosus & & 1.6 & 0.63 & 0.065 & 1.0 & 10 & 46 & $23^{\mathrm{b}}$ & M & & 32 \\
\hline Polistes chinensis $\left(^{*}\right)$ & & 1 & $0.75^{\mathrm{a}}$ & 0.125 & 51.1 & 22 & 563 & 446.6 & M & & 33 \\
\hline Polistes dorsalis & & 1 & $0.75^{\mathrm{a}}$ & 0.125 & 0.0 & 6 & 51 & $25.5^{\mathrm{b}}$ & M & & 32 \\
\hline Polistes fuscatus variatus $\left(^{*}\right)$ & & 1.5 & 0.50 & 0.020 & 0.0 & 4 & 53 & 26.5 & A & & 34 \\
\hline Polistes gallicus & & 1 & $0.75^{\mathrm{a}}$ & 0.125 & 0.0 & 5 & 31 & $15.5^{b}$ & M & & 35 \\
\hline Polistes metricus $\left({ }^{*}\right)$ & & 1.03 & 0.65 & 0.076 & 1.3 & 6 & 152 & 76 & A & & 34 \\
\hline \multicolumn{12}{|l|}{ VESPINAE WASPS } \\
\hline Dolichovespula arenaria $\left({ }^{*}\right)$ & & 1 & $0.71^{\mathrm{a}}$ & 0.104 & 17.0 & 9 & 472 & 236 & A & & 36 \\
\hline Dolichovespula maculata & & 1 & $0.75^{\mathrm{a}}$ & 0.125 & 20.9 & 7 & 202 & 153.3 & M & & 37 \\
\hline Dolichovespula media & & 1 & $0.71^{\mathrm{a}}$ & 0.105 & 7.4 & 8 & 229 & 148 & M & & 37 \\
\hline Dolichovespula norwegica & & 1 & $0.71^{\mathrm{a}}$ & 0.105 & 2.6 & 8 & 206 & 151.8 & M & & 37 \\
\hline Dolichovespula saxonica & LP & 1 & $0.65^{\mathrm{a}}$ & 0.075 & 40.0 & 8 & 205 & 143.2 & $\mathrm{M}$ & $p=0.004^{\mathrm{d}}$ & 38 \\
\hline
\end{tabular}


Table A2 (Continued)

\begin{tabular}{|c|c|c|c|c|c|c|c|c|c|c|c|}
\hline $\begin{array}{l}\text { TAXON } \\
\text { Species }\end{array}$ & $\begin{array}{l}\text { Colony class } \\
\text { or study }\end{array}$ & $N_{e}$ & $r_{w-w}$ & $r_{\text {diff }}$ & $W P M$ & $n_{c}$ & $n_{m}$ & $n_{a}$ & Met & SIV & Refs. \\
\hline Dolichovespula saxonica & $\mathrm{HP}$ & 1 & $0.46^{\mathrm{a}}$ & -0.020 & 0.0 & 1 & 30 & 15 & $\mathrm{M}$ & & 38 \\
\hline Dolichovespula saxonica & all & 1 & $0.62^{\mathrm{a}}$ & 0.060 & 36.7 & 9 & 235 & 158.2 & M & & 38 \\
\hline Dolichovespula sylvestris & & 1 & $0.68^{\mathrm{a}}$ & 0.090 & 9.8 & 10 & 220 & 153.5 & M & & 37 \\
\hline Vespa crabro flavofasciata $\left(^{*}\right)$ & & 1 & $0.72^{\mathrm{a}}$ & 0.110 & 0.0 & 13 & 260 & 231 & M & & 39 \\
\hline Vespa crabo gribodi & & 1 & $0.67^{\mathrm{a}}$ & 0.085 & 0.0 & 14 & 282 & 176 & M & & 40 \\
\hline Vespa ducalis $\left(^{*}\right)$ & & 1 & $0.75^{\mathrm{a}}$ & 0.125 & 0.0 & 20 & 400 & 257 & M & & 41 \\
\hline Vespa mandarinia $(*)$ & & 1 & 0.70 & 0.100 & 0.0 & 20 & 400 & 321 & M & & 42 \\
\hline Vespula germanica $\left.{ }^{* *}\right)$ & & 1 & $0.45^{\mathrm{a}}$ & -0.024 & 0.0 & 4 & 255 & 190.1 & M & & 43 \\
\hline Vespula maculifrons $\left({ }^{*}\right)$ & & 1 & 0.32 & -0.090 & 0.0 & 15 & 1,446 & 172 & A & & 44 \\
\hline Vespula rufa & LP & 1 & $0.61^{\mathrm{a}}$ & 0.056 & 3.3 & 9 & 211 & 188.8 & M & $N S^{\mathrm{d}}$ & 45 \\
\hline Vespula rufa & HP & 1 & $0.44^{\mathrm{a}}$ & -0.028 & 18.5 & 4 & 131 & 107.5 & M & & 45 \\
\hline Vespula rufa $\left.{ }^{*}\right)$ & all & 1 & $0.58^{\mathrm{a}}$ & 0.040 & 11.1 & 13 & 342 & 296.3 & M & & 45 \\
\hline Vespula squamosa $(*)$ & & 1 & 0.40 & -0.050 & 0.0 & 7 & 548 & 170 & A & & 44 \\
\hline Vespula vulgaris & & 1 & 0.51 & $0.005^{\mathrm{e}}$ & 0.0 & 9 & 270 & 171 & M & & 46 \\
\hline \multicolumn{12}{|l|}{ ANTS } \\
\hline Acromyrmex echinatior $\left({ }^{\star}\right)$ & & 1 & 0.35 & -0.075 & 0.0 & $N A$ & 232 & $116^{\mathrm{b}}$ & M & & 47 \\
\hline Acromyrmex octospinosus $\left({ }^{*}\right)$ & & 1 & 0.33 & -0.085 & 0.0 & $N A$ & 122 & $66^{\mathrm{b}}$ & A & & 48 \\
\hline Aphaenogaster carolinensis $\left({ }^{*}\right)$ & & 1 & $0.75^{\mathrm{a}}$ & 0.125 & 0.0 & 6 & 42 & 21 & A & & 49 \\
\hline Camponotus ocreatus $\left({ }^{*}\right)$ & & 1 & $0.75^{\mathrm{a}}$ & 0.125 & 0.0 & 2 & 29 & 14.5 & M & & 50 \\
\hline Colobopsis nipponicus $\left(^{*}\right)$ & & 1 & $0.75^{\mathrm{a}}$ & 0.125 & 0.0 & 6 & 60 & 30 & A & & 51 \\
\hline Crematogaster smithi & & 1 & $0.75^{\mathrm{a}}$ & 0.125 & 11.0 & 4 & 55 & 27.5 & M & & 52 \\
\hline Cyphomyrmex costatus & & 1 & $0.75^{\mathrm{a}}$ & 0.125 & 0.0 & 3 & 17 & $8.5^{\mathrm{b}}$ & M & & 53 \\
\hline Cyphomyrmex longiscapus & & 1 & $0.75^{\mathrm{a}}$ & 0.125 & 0.0 & 3 & 18 & $9^{\mathrm{b}}$ & M & & 53 \\
\hline Dinoponera quadriceps $\left({ }^{*}\right)$ & & 1 & $0.75^{\mathrm{a}}$ & 0.125 & 8.5 & 15 & 73.5 & 73.5 & B & & 54 \\
\hline Dorylus molestus $\left(^{*}\right)$ & & 1.4 & $0.24^{\mathrm{a}}$ & -0.103 & 0.0 & 8 & 176 & 126 & M & & 55 \\
\hline Epimyrma ravouxi & & 1 & $0.75^{\mathrm{a}}$ & 0.125 & 0.0 & 7 & 47 & 27.5 & M & & 56 \\
\hline Formica exsecta $\left(^{*}\right)$ & LP, study 1 & 1 & $0.75^{\mathrm{a}}$ & 0.125 & 10.0 & 2 & 20 & 10 & A & & 57 \\
\hline Formica exsecta & LP, study 2 & 1 & 0.62 & 0.060 & 0.0 & 35 & 409 & 205 & M & & 58 \\
\hline Formica exsecta $(* *)$ & LP, comb. est. & & 0.63 & 0.064 & 0.5 & 37 & 429 & 215 & $\mathrm{M}+\mathrm{A}$ & NS & \\
\hline Formica exsecta & $\mathrm{HP}$ & 1 & 0.46 & -0.020 & 0.0 & 3 & 30 & 15 & M & & 58 \\
\hline Formica exsecta $\left({ }^{* *}\right)$ & all & 1 & 0.62 & 0.060 & 0.4 & 40 & 459 & 230 & $\mathrm{M}+\mathrm{A}$ & & \\
\hline Formica fusca $\left.{ }^{*}\right)$ & & 3.3 & 0.31 & $-0.0008^{e}$ & 0.0 & 30 & 600 & $300^{b}$ & A & & 59 \\
\hline Formica rufa $\left({ }^{*}\right)$ & LP & 1 & 0.75 & 0.125 & 5.3 & 51 & 1020 & $510^{\mathrm{b}}$ & A & & 60 \\
\hline Formica rufa $\left({ }^{*}\right)$ & HP & 1 & 0.50 & 0.000 & 3.9 & 28 & 560 & $280^{b}$ & A & & 60 \\
\hline Formica rufa $\left(^{*}\right)$ & all & 1 & 0.59 & 0.045 & 4.8 & 79 & 1580 & $790^{\mathrm{b}}$ & A & & 60 \\
\hline Formica sanguinea $\left({ }^{*}\right)$ & & 1.2 & 0.56 & 0.030 & 3.2 & 5 & 63 & 31.5 & A & & 61 \\
\hline Formica truncorum $\left({ }^{*}\right)$ & & 1 & 0.60 & 0.050 & 0.0 & 30 & 900 & $450^{\mathrm{b}}$ & A & & 62 \\
\hline Harpagoxenus sublaevis $\left({ }^{*}\right)$ & & 1 & $0.75^{\mathrm{a}}$ & 0.125 & 0.0 & 2 & 58 & 29 & A & & 63 \\
\hline Iridomyrmex purpureus $\left({ }^{*}\right)$ & & 1 & $0.75^{\mathrm{a}}$ & 0.125 & 0.0 & 2 & 14 & 7 & A & & 64 \\
\hline Lasius niger $\left({ }^{*}\right)$ & LP & 1 & 0.64 & 0.070 & 9.4 & 16 & 307 & $153.5^{b}$ & A & & 65 \\
\hline Lasius niger & LP & 1 & 0.69 & 0.095 & 1.9 & 33 & 157 & 107.5 & M & & 66 \\
\hline Lasius niger $\left({ }^{* *}\right)$ & LP, comb. est. & 1 & 0.67 & 0.087 & 4.4 & 49 & 464 & 261 & $\mathrm{M}+\mathrm{A}$ & NS & \\
\hline Lasius niger & HP. & 1 & 0.45 & -0.025 & 2.1 & 13 & 65 & 46.75 & M & & 66 \\
\hline Lasius niger $\left({ }^{*}\right)$ & all & 1 & 0.63 & 0.063 & 3.9 & 62 & 529 & 307.75 & $\mathrm{M}+\mathrm{A}$ & & \\
\hline Leptothorax acervorum & MON & 1 & $0.75^{\mathrm{a}}$ & 0.125 & 2.3 & 11 & 242 & 220.3 & M & NS & 67 \\
\hline Leptothorax acervorum & POL & 3.6 & 0.28 & 0.005 & 4.6 & 8 & 86 & 65.9 & M & & 67 \\
\hline Leptothorax acervorum & all & 2.1 & 0.52 & 0.083 & 2.8 & 20 & 328 & 286.2 & M & & 67 \\
\hline Leptothorax allardycei $\left({ }^{*}\right)$ & & 1 & $0.75^{\mathrm{a}}$ & 0.125 & 35.8 & 1 & 114 & 114 & $\mathrm{~B}$ & & 68 \\
\hline Leptothorax nylanderi & & 1 & 0.59 & 0.045 & 2.5 & 33 & 163 & 81.5 & M & & 69 \\
\hline Leptothorax unifasciatus & & 1 & $0.75^{\mathrm{a}}$ & 0.125 & 2.7 & 10 & 80 & 73.4 & M & & 70 \\
\hline Myrmica punctiventris & & 1 & 0.73 & 0.115 & 58.0 & 27 & 242 & 162.7 & M & & 71 \\
\hline Myrmica ruginodis $\left({ }^{*}\right)$ & & 1.7 & 0.49 & 0.060 & 0.0 & 30 & 289 & $144.5^{\mathrm{b}}$ & A & & 72 \\
\hline Myrmica tahoensis & $\mathrm{MON}$ & 1 & $0.75^{\mathrm{a}}$ & 0.125 & 65.1 & 9 & 35 & 21.5 & M & NS & 73 \\
\hline Myrmica tahoensis & POL & 1.7 & 0.57 & -0.025 & 84.8 & 2 & 13 & 8.25 & M & & 73 \\
\hline Myrmica tahoensis & all & 1.1 & 0.72 & 0.098 & 70.6 & 11 & 48 & 29.75 & M & & 73 \\
\hline Nothomyrmecia macrops & & 1 & 0.61 & 0.055 & 0.0 & 6 & 21 & 18.6 & M & & 74 \\
\hline Pogonomyrmex rugosus $\left({ }^{*}\right)$ & & 1 & 0.32 & -0.090 & 0.0 & 19 & 198 & 155 & M & & 75 \\
\hline Polyergus rufescens $\left({ }^{*}\right)$ & & 1 & $0.75^{\mathrm{a}}$ & 0.125 & 100 & 4 & 170 & 127.5 & M & & 76 \\
\hline Protomognathus americanus & & 1 & 0.68 & 0.090 & 41.0 & 4 & 13 & $6.5^{\mathrm{b}}$ & M & & 77 \\
\hline Rhytidoponera chalybaea $\left({ }^{*}\right)$ & (queen cols.) & 1 & $0.75^{\mathrm{a}}$ & 0.125 & 0.0 & 16 & 453 & $226.5^{\mathrm{b}}$ & A & & 78 \\
\hline Rhytidoponera confusa $\left(^{*}\right)$ & (queen cols.) & 1 & $0.75^{\mathrm{a}}$ & 0.125 & 0.0 & 16 & 213 & $106.5^{b}$ & A & & 78 \\
\hline Sericomyrmex amabilis & & 1 & $0.75^{a}$ & 0.125 & 0.0 & 2 & 19 & $9.5^{\mathrm{b}}$ & M & & 53 \\
\hline Trachymyrmex cornetzi sp.1 & & 1 & $0.75^{\mathrm{a}}$ & 0.125 & 0.0 & 3 & 20 & $10^{\mathrm{b}}$ & M & & 53 \\
\hline Trachymyrmex cf. zeteki & & 1 & $0.75^{\mathrm{a}}$ & 0.125 & 0.0 & 4 & 30 & $15^{\mathrm{b}}$ & M & & 53 \\
\hline
\end{tabular}

Note: Data on 50 species are largely based on the review of Hammond and Keller (2004); data from a further 40 species, indicated by an asterisk, are newly added. Double asterisks indicate cases where the Hammond and Keller (2004) estimate was altered due to the inclusion of additional studies or reanalysis of the original data. Colony class: $\mathrm{LP}=$ low paternity; HP=high paternity; MON=monogynous; 
$\mathrm{POL}=$ polygynous; cols.=colonies; comb. est.=combined estimate; $\mathrm{Ne}=$ effective number of queens; $r \mathrm{w}$ w=worker-worker relatedness; rdiff=difference in relatedness between workers' sons and queen's sons; WPM=percentage of worker-produced males; nc, $\mathrm{nm}$ and $\mathrm{na}=$ number of colonies and absolute and assignable number of males assayed for male parentage; Met=method used to estimate WPM: M (microsatellites), A (allozymes), D (DNA fingerprinting), P (recessive phenotypic marker) or B (behavioral observation); $\mathrm{SIV}=$ significance of intraspecific variation in male parentage; $\mathrm{NA}=$ not available.

${ }^{a}$ Pedigree relatedness estimate. A value of 0.75 was used for all species where colonies were headed by a single queen and genetic evidence for multiple mating or frequent queen turnover were absent. This avoided spurious contrasts being introduced as a result of sampling error on regression relatedness estimates. However, using regression relatedness throughout led to the same overall conclusions. ${ }^{\mathrm{b}}$ Maximum-likelihood method used or number of assignable males not reported; it was conservatively assumed that there was only one informative locus and that the power to detect workers' sons was $50 \%$, giving $n_{a}=n_{m} / 2$. ' Some of these males were the offspring of workers that had drifted from other colonies (Lopez-Vaamonde et al. 2004). ${ }^{\mathrm{d}}$ Based on published correlations between relatedness and the percentage of males that were workers' sons. ${ }^{\mathrm{e}} \boldsymbol{r}_{\text {diff }}$ was not significantly different from zero (see notes below).

References: 1 Mueller et al. 1994; 2 Packer and Owen 1994; 3 Richards et al. 2005; 4 Crozier et al. 1987; Kukuk and May 1991; 5 Paxton et al. 2001b; R. Paxton, pers. comm.; 6 Brown et al. 2003; M. Brown, pers. comm.; 7 Owen and Plowright 1980, 1982; 8 Lopez-Vaamonde et al. 2004; 9 Alaux et al. 2004; 10 Velthuis et al. 2002; M.J. Duchateau, pers. comm.; 11 Drumond et al. 2000; 12 Palmer et al. 2002; 13 Paxton et al. 2001a; 14 Sommeijer et al. 1999; Chinh et al. 2003; 15 Tóth et al. 2002b; 16 Contel and Kerr 1976; 17 Koedam et al. 1999; Koedam et al. 2005; 18 Tóth et al. 2002a; 19 Machado et al. 1984; 20 Paxton et al. 2003; 21 Tóth et al. 2003; 22 Green and Oldroyd 2002; 23 Palmer et al. 2002; 24 Palmer and Oldroyd 2000; Oldroyd et al. 2001; 25 Palmer and Oldroyd 2000; Wattanachaiyingcharoen et al. 2002; 26 Palmer and Oldroyd 2000; Halling et al. 2001; 27 Visscher 1989; Estoup et al. 1994; Palmer and Oldroyd 2000; 28 Ross and Matthews 1989; 29 Hastings et al. 1998; 30 Henshaw et al. 2000a; 31 Henshaw et al. 2002; 32 Arévalo et al. 1998; 33 Tsuchida et al. 2003; Saigo and Tsuchida 2004; K. Tsuchida, pers. comm.; 34 Metcalf 1980; 35 Strassmann et al. 2003; 36 Foster and Ratnieks 2001b; F.L.W. Ratniek and J.J. Boomsma, pers. comm.; 37 Foster et al. 2001; 38 Foster and Ratnieks 2000; 39 Takahashi et al. 2004b; 40 Foster et al. 2000; 41 Takahashi et al. 2002; 42 Takahashi et al. 2004a; 43 T. Wenseleers, R.L. Hammond, K. Vuerinckx, J. Billen and L. Keller, unpublished data; see notes below; 44 Ross 1986; 45 Wenseleers et al. 2005a; 46 Foster and Ratnieks 2001a; 47 Bekkevold et al. 1999; number of males genotyped: M.B. Dijkstra, pers. comm.; 48 Boomsma et al. 1999; Villesen et al. 1999; 49 Crozier 1974; 50 Goodisman and Hahn 2004; 51 Hasegawa 1994; 52 Heinze et al. 2000; 53 Villesen et al. 2002; Villesen and Boomsma 2003; 54 Monnin and Peeters 1997; 55 Kronauer et al. 2006; 56 Hammond and Keller 2004; 57 Pamilo and Rosengren 1983; 58 Sundström et al. 1996; Walin et al. 1998; 59 Helanterä and Sundström 2005; L. Sundström, pers. comm.; 60 Walin et al. 1998; L. Sundström, pers. comm.; 61 Pamilo 1982; Pamilo and Rosengren 1983; 62 Sundström 1994; L. Sundström, pers. comm.; 63 Bourke et al. 1988; 64 Halliday 1983; 65 van der Have et al. 1988; 66 Fjerdingstad et al. 2002; Fjerdingstad et al. 2003; 67 Chan and Bourke 1994; Hammond et al. 2003; 68 Cole 1981; 69 Foitzik 1998; Foitzik and Heinze 2001; 70 Hammond and Keller 2004; 71 Herbers and Mouser 1998; 72 Walin et al. 1998; P. Seppä, pers. comm.; 73 Evans 1998; J. Evans, pers. comm.; 74 Sanetra and Crozier 2001; 75 Hammond et al. 2004; R.L. Hammond, pers. comm.; 76 Brunner et al. 2005; 77 Foitzik and Herbers 2001; 78 Ward 1983

Notes on the procedures used to estimate relatedness and male parentage: Below we give some technical details on the procedures used to estimate relatedness and the percentage of males that are workers' sons (WPM). For species that are not explicitly mentioned, estimates were taken directly from the review of Hammond and Keller (2004) or from the original published source. A worker's son can be identified using genetic markers whenever it contains an allele that could only be inherited from the queen's mate. If a single informative locus is available, this results in a detection power of $50 \%$. Unless otherwise noted, all estimates of WPM take into account detection power. SWEAT BEES: A. striata. We only included data from colonies headed by a primary queen ("eusocial colonies"), where no evidence for worker reproduction was found (Mueller et al. 1994). In colonies which had lost the primary queen ("parasocial colonies"), and where a mated worker had taken over reproduction, an estimated $9.3 \%$ of the males were the workers' sons (Mueller et al. 1994). Nevertheless, because such colonies experience a short period of queenlessness during which males could have been produced, data from parasocial colonies were not included. L. laevissimum. The regression relatedness of workers to the males reared was $r_{w-m}=0.63$, and significantly higher than the value of 0.5 expected if all males were the queen's sons (Packer and Owen 1994). The proportion of males that were the workers' sons $\psi$ was estimated from the equation $r_{w-m}=\psi(3 / 4)+(1-\psi) .(1 / 2)$, which gave $\psi=0.52$, i.,e. WPM $=52 \%$. BUMBLEBEES: B. melanopygus. Estimate of WPM is based on the screening of 1,125 males using the Mendelianly inherited abdominal pile coloration marker (Owen and Plowright 1980). Since the power to detect workers' sons differed among colonies, WPM was estimated using a maximum-likelihood approach (Owen and Plowright 1982). B. terrestris. Estimate of WPM is based on two microsatellite studies (Lopez-Vaamonde et al. 2004 and Alaux et al. 2004) and one study which used a heritable body color marker, created by crossing two Bombus terrestris subspecies, B. terrestris terrestris and B. terrestris sassaricus (Velthuis et al. 2002). All three studies used a maximumlikelihood approach to estimate WPM and gave good agreement, with 2.3-4.8\% of the males being workers' sons. STINGLESS BEES: $\boldsymbol{M}$. $\boldsymbol{f a}$ vosa. Behavioral studies show that $94.5 \%$ of the males are workers' sons (Sommeijer et al. 1999; Chinh et al. 2003). The colony kin structure of this species has not been studied using genetic methods. However, since single mating is the rule in stingless bees (Peters et al. 1999; Strassmann 2001), we set $r_{w-w}=0.75$. M. subnitida. Male parentage has been investigated using allozymes (Contel and Kerr 1976) and behavioral study (Koedam et al. 1999; Koedam et al. 2005). The estimate of WPM for the behavioral studies was taken directly from the published sources. For the allozyme study, we calculated the average WPM based on 14 colonies with parental genotypes $\mathrm{AB} \times \mathrm{A}$ and 4 colonies with parental genotypes AA x B (or BB x A) (Contel and Kerr 1976). Two colonies which had fewer than 10 males genotyped were excluded. For the 4 colonies where all workers were heterozygous, the parental genotypes were reconstructed in such a way that it resulted in the most conservative estimate of WPM (e.g. if 9 males were A and 1 male B, the parental genotypes were assumed to be an AA queen mated to a B male as opposed to a BB queen mated to an A male). Out of these 4 colonies, 3 had both A and B males present, showing that worker reproduction was definitely present. For the remaining 14 colonies, WPM was estimated based on statistical deviations from the 1 to 1 ratio expected under exclusive queen production of males. P. droryana. A microsatellite study based on the analysis of 19 males from 1 colony was unable to detect male production by workers (Tóth et al. 2002b). However, a larger allozyme study, based on the analysis of 281 males from 14 colonies inferred that $16.2 \%$ of the males were workers' sons (Machado et al. 1984). This conclusion was based on statistically significant deviations from a 1 to 1 ratio expected under exclusive queen production of males in $\mathrm{AB} \times \mathrm{A}$ crosses. Note that the putative evidence for multiple mating in a few species of stingless bees has since been overturned and has been shown to be due to the accidental inclusion of drifted workers (Paxton et al. 2001a; Palmer et al. 2002). HoneybeEs: A. mellifera. The estimate of WPM was based on the screening of 57,960 males using the cordovan marker (Rothenbuhler et al. 1968). This marker could positively identify $50 \%$ of the workers' sons. The study colonies all had the genotype cc (queen) x C, C, C....C (males). As a result all the workers were $\mathrm{Cc}$ and half of their male offspring had wild type body color (C) and were detectable. All queen's sons and half the workers' sons had cordovan body color (c). Polistinae WASPS: B. mellifica, P. colobopterus, P. tabidus (Epiponini). Hammond and Keller 
(2004) mention that "likelihood analysis showed that almost all males were queen-produced, although there was a possibility of a small amount of worker reproduction. In view of this we set the proportion of worker-produced males to $5 \%$ for each species". Here we used a more exact approach, and used the overall, population-wide maximum-likelihood estimates of the proportion of males that were workers' sons, which were $2 \%$ (Henshaw et al. 2000b), $0 \%$ (Hastings et al. 1998) and $0 \%$ (Henshaw et al. 2000a), respectively. Individual colony-level maximum likelihood estimates could not be used as these were too uncertain for some colonies (Hastings et al. 1998; Henshaw et al. 2000a; Henshaw et al. 2002). In the Epiponini, worker policing remains to be directly shown, although oophagy of worker-laid eggs has been observed in Protopolybia acutiscutis (Naumann 1970) and P. exigua (Simões 1977). P. chinensis. The published value for WPM of 39.1\% (Tsuchida et al. 2003) had not been corrected for the power the power to detect workers' sons, $79.3 \%$ (K. Tsuchida, pers. comm.). The corrected value for WPM is 51.1\%. VeSPINAE WASPS: $V$. germanica. Based on the analysis of 255 males from 4 colonies using ca. 2 informative microsatellite markers, all males were found to be queen's sons (T. Wenseleers, R.L. Hammond, K. Vuerinckx, J. Billen and L. Keller, unpublished data, $\left.n_{a}=190.1\right)$. All 4 colonies had an effective paternity greater than 2 and the harmonic mean effective paternity was 2.93 . Another less extensive study $\left(n_{a}=62.2\right)$ also supported queen production of males for 11 out of 12 colonies (Goodisman et al. 2002). For the $12^{\text {th }}$ colony, however, data were either consistent with two matrilines being present as a result of queen takeover (Wenseleers et al. 2005a), or with worker parentage of some of the males (Hammond and Keller 2004). Because of this ambiguity, the Goodisman et al. (2002) study was excluded. The worker-worker relatedness that is given is a weighted average of the relatedness in 17 colonies analyzed by Goodisman et al. (2002) $\left(r_{w-w}=0.46\right)$ and in 4 colonies analyzed by Hammond et al. (in prep.) $\left(r_{w-w}=0.42\right)$, giving $r_{w-w}=0.45$ and $r_{\text {diff }}=-0.024$. V. rufa. Colonies were split into those with effective paternity $\leq 2$ and $>2$, and WPM was estimated for these two colony classes based on the original microsatellite data (Wenseleers et al. 2005a). $V$. vulgaris. $r_{\text {diff }}$ was 0.005 , and not significantly different from zero (95\% confidence limits: [-0.015,0.025], Foster and Ratnieks 2001a). ANTS: D. quadriceps. Colonies of this species are headed by a single queen (who is actually a mated worker or 'gamergate') (Monnin and Peeters 1997). Behavioral study showed that the percentage of eggs laid by workers $p$ is $14.0 \%$ (18/129) (Monnin and Peeters 1997). The probability that queen-laid eggs were reared into adulthood was $s_{q}=0.975$, since 39 out of 40 of her eggs were added to the egg pile without being eaten. The probability that worker-laid eggs were reared into adulthood, however, was lower, $s_{w}=0.28$, since only 5 out of the 18 worker-laid eggs escaped being policed by the queen (see notes of Table A1). The 5 eggs, however, did develop, since they remained in the egg pile until they darkened, and darkened eggs were never observed to be eaten (Monnin and Peeters 1997). Assuming that the gamergate laid male and female eggs in approx. an equal ratio $W P M=p \cdot s_{w} /\left(p \cdot s_{w}+(1-p) .(1 / 2) \cdot s_{q}\right)=8.5 \%$. This is a conservative estimate since the gamergate's eggs would mostly have been female, and destined to be reared into more workers. Behavioral observation has shown that gamergates in this species are single mated, since after mating, the genitals of the male and part of its abdomen remain attached to the female. This acts as a mating plug and prevents further matings (Monnin and Peeters 1998). Note that worker policing via egg-eating in this species is also absent (Table A1). F. exsecta. In an allozyme-based study, one out of 20 males collected from two colonies with informative genotypes was the son of a worker (Pamilo and Rosengren 1983). Another microsatellite-based study found no evidence for worker reproduction in this species (Sundström et al. 1996; Walin et al. 1998). Based on the two studies combined, the estimate of WPM is $0.4 \%$. A low level of worker reproduction is also supported by a forthcoming microsatellite-based study (C. Liautard, E. Vitikainen and L. Sundström, pers. comm.). F. fusca. Absence of worker reproduction was inferred based on allozyme genotyping of 30 monogynous colonies (L. Sundström, pers. comm.). Based on microsatellite analysis, however, the mean effective queen number $N_{e}$ and queen-queen relatedness $G$ across two study populations has been measured at 3.25 and 0.455 (Hannonen et al. 2004). This gives a mean $r_{w-w}=\left(3+G\left(N_{e}-1\right) / 4 N_{e}=0.31\right.$ and $r_{\text {diff }}=r_{w-w m}-r_{w-q m}=r_{w-w} / 2-\left(1+G\left(N_{e}-1\right)\right) / 4 N_{e}=-0.0008$ (Pamilo 1991). Because $r_{\text {diff }}$ was actually slightly greater than zero in one of the study populations and slightly below zero in the other, we considered $r_{\text {diff }}$ to be not significantly different from zero (Hannonen et al. 2004; Helanterä and Sundström 2005). F. rufa. Colonies were divided in those headed by multiple-mated and single-mated queens (Walin et al. 1998, L. Sundström, pers. comm.). Out of 28 colonies headed by multiple-mated queens, two had evidence for worker reproduction, and 11 out of 560 males were workers' sons. Out of 51 colonies headed by single-mated queens, six had evidence for worker reproduction, and 27 out of 1020 males were workers' sons. The exact power to detect workers' sons across all colonies was unknown, but we conservatively assumed it was 50\%. This gave an estimate of WPM for the single-paternity and multiple-paternity colonies of 5.3\% and 3.9\% and $4.8 \%$ overall. $\boldsymbol{H}$. sublaevis. For this species, we only included two colonies for which all workers were heterozygous and which were actually informative (Bourke et al. 1988). L. niger. WPM was estimated based on a microsatellite (Fjerdingstad et al. 2002; Fjerdingstad et al. 2003) and an allozyme study (van der Have et al. 1988). For the latter study, Van der Have et al. (1988) inferred that workerproduced male pupae were present in two out of 16 queenright colonies for which loci were informative. The maximum-likelihood estimates of WPM for those two colonies were that $70 \%$ and $100 \%$ of all males were workers' sons, giving an overall estimate of $W P M=9.44 \%$. The effective paternity estimates were below 2 for all colonies. Estimates were combined with those of Fjerdingstad et al. $(2002,2003)$ using weighted averages. $L$. allardycei. Using a color dye, it was shown that the percentage of eggs laid by workers $p$ is $21.8 \%$ (41/187) (Cole 1981). Given that these eggs underwent normal development, and assuming that the queen laid male and female eggs in an equal ratio, $W P M=p /(p+(1-p) .(1 / 2))=35.8 \%$. This is a conservative estimate since the queen's eggs probably contained a majority of female worker-destined eggs. The colony kin structure of this species has not been studied using genetic methods. However, colonies are always headed by a single queen and queens of other leptothoracine ants have generally been shown to be single mated (Heinze et al. 1997, Table A2). Hence, we set $r_{w-w}=0.75$ and $r_{\text {diff }}=0.125$. L. unifasciatus. The percentage of worker-produced males WPM was estimated based on the genotyping of eggs rather than adult males (Hammond and Keller 2004). Nevertheless, because both worker and queen policing has been shown to be absent in this species (Stroeymeyt et al. 2006), the percentage of adult worker-produced males is probably the same. In addition, the genotyped eggs likely contained mostly older eggs. M. tahoensis. In Hammond and Keller (2004) the overall relatedness of the monogynous and polygynous colony classes combined was lower than that of each class individually, which is impossible. Here, the correct overall relatedness estimate is given. $\boldsymbol{R}$. chalybaea and $\boldsymbol{R}$. confusa. We only included data from colonies headed by a primary queen, where no evidence for worker reproduction was found (Ward 1983). In colonies which had lost the primary queen, and where one or several mated workers had taken over reproduction, a small percentage of the males were inferred to be the workers' sons (Ward 1983). Nevertheless, because such colonies experience a short period of queenlessness during which males could have been produced, data from the latter type of colonies were not included.

\section{Literature Cited in the Appendix}

Alaux, C., F. Savarit, P. Jaisson, and A. Hefetz. 2004. Does the queen win it all? Queen-worker conflict over male production in the bumblebee, Bombus terrestris. Naturwissenschaften 91:400403.

Anderson, R. H. 1963. The laying worker in the cape honeybee, Apis mellifera capensis. Journal of Apiculture Research 2: 85-92.
Arévalo, E., J. E. Strassmann, and D. C. Queller. 1998. Conflicts of interest in social insects: male production in two species of Polistes. Evolution 52:797-805.

Baer, B., E. D. Morgan, and P. Schmid-Hempel. 2001. A nonspecific fatty acid within the bumblebee mating plug prevents females from remating. Proceedings of the National Academy of 
Sciences of the USA 98:3926-3928.

Batra, S. W. T. 1968. Behavior of some social and solitary halictine bees within their nests; a comparative study (Hymenoptera: Halictidae). Journal of the Kansas Entomological Society 41:120133.

Beekman, M., C. G. Martin, and B. P. Oldroyd. 2004. Similar policing rates of eggs laid by virgin and mated honey- bee queens. Naturwissenschaften 91:598-601.

Bekkevold, D., J. Frydenberg, and J. J. Boomsma. 1999. Multiple mating and facultative polygyny in the Panamanian leafcutter ant Acromyrmex echinatior. Behavioral Ecology and Sociobiology 46:103-109.

Bloch, G., and A. Hefetz. 1999. Regulation of reproduction by dominant workers in bumblebee (Bombus terrestris) queenright colonies. Behavioral Ecology and Sociobiology 45:125-135.

Boomsma, J. J., E. J. Fjerdingstad, and J. Frydenberg. 1999. Multiple paternity, relatedness and genetic diversity in Acromyrmex leaf-cutter ants. Proceedings of the Royal Society of London Series B-Biological Sciences 266:249-254.

Bourke, A. F. G. 1988a. Dominance orders, worker reproduction, and queen-worker conflict in the slave-making ant Harpagoxenus sublaevis. Behavioral Ecology and Sociobiology 23:323-333.

-. 1991. Queen behavior, reproduction and egg cannibalism in multiple-queen colonies of the ant Leptothorax acervorum. Animal Behaviour 42:295-310.

Bourke, A. F. G., T. M. van der Have, and N. R. Franks. 1988. Sex ratio determination and worker reproduction in the slavemaking ant Harpagoxenus sublaevis. Behavioral Ecology and Sociobiology 23:233-245.

Brian, A. D. 1951. Brood development in Bombus agrorum (Hym., Bombidae). Entomologist's Monthly Magazine 87:207-212.

-. 1952. Division of labour and foraging in Bombus agrorum Fabricius. Journal of Animal Ecology 21:223-240.

Brown, M. J. F., R. Schmid-Hempel, and P. Schmid-Hempel. 2003. Queen-controlled sex ratios and worker reproduction in the bumble bee Bombus hypnorum, as revealed by microsatellites. Molecular Ecology 12:1599-1605.

Brunner, E., A. Trindl, K. H. Falk, J. Heinze, and P. D'Ettorre. 2005. Reproductive conflict in social insects: male production by workers in a slave-making ant. Evolution 59:2480-2482.

Buckle, G. R. 1982. Queen-worker behavior and nesmate interactions in young colonies of Lasioglossum zephyrum. Insectes Sociaux 29:125-137.

Chan, G. L., and A. F. G. Bourke. 1994. Split sex-ratios in a multiple-queen ant population. Proceedings of the Royal Society of London Series B-Biological Sciences 258:261-266.

Chinh, T. X., G. B. J. Grob, F. J. A. J. Meeuwsen, and M. J. Sommeijer. 2003. Patterns of male production in the stingless bee Melipona favosa (Apidae, Meliponini). Apidologie 34:161-170.

Cnaani, J., R. Schmid-Hempel, and J. O. Schmidt. 2002. Colony development, larval development and worker reproduction in Bombus impatiens Cresson. Insectes Sociaux 49:164-170.

Cole, B. J. 1981. Dominance hierarchies in Leptothorax ants. Science 212: 83-84.

Crozier, R. H. 1974. Allozyme analysis of reproductive strategy in the ant Aphaenogaster rudis. Isozyme Bulletin 7:18.

Crozier, R. H., B. H. Smith, and Y. C. Crozier. 1987. Relatedness and population structure of the primitively Eusocial bee Lasioglossum zephyrum (Hymenoptera, Halictidae) in Kansas. Evolution 41:902-910.

Cumber, R. A. 1949. The biology of humble bees with special reference to the production of the worker caste. Transactions of the Royal Entomological Society of London 100:1-44.
Dampney, J. R., A. B. Barron, and B. P. Oldroyd. 2002. Policing of adult honey bees with activated ovaries is error-prone. Insectes Sociaux 49:270-274.

da Silva, P. R., L. R. Bego, and S. F. Sakagami. 2001. On the cell provisioning and oviposition process (POP) of the stingless bee Scaptotrigona aff. depilis (Hymenoptera: Meliponinae). Sociobiology 38:615-638.

Dijkstra, M., and J. J. Boomsma. 2004. Reproductive self-restraint without effective policing in workers of Acromyrmex echinatior leafcutter ants. Page 20, in Integrated Studies of Social Evolution - The Closing Symposium of the EU Research Training Network INSECTS, Lo-Skolen, Helsingoer, Denmark.

Dijkstra, M. B., D. R. Nash, and J. J. Boomsma. 2005. Self-restraint and sterility in workers of Acromyrmex and Atta leafcutter ants. Insectes Sociaux 52:67-76.

Drumond, P. M., B. P. Oldroyd, and K. Osborne. 2000. Worker reproduction in Austroplebeia australis Friese (Hymenoptera, Apidae, Meliponini). Insectes Sociaux 47:333-336.

- 1996 . Is kin conflict expressed in the colony cycle of the bumble bee Bombus terrestris? In: Proceedings of the XXth International Congress of Entomology, p. 404.

Duchateau, M. J., and H. H. W. Velthuis. 1988. Development and reproductive strategies in Bombus terrestris colonies. Behaviour 107:186-207.

Estoup, A., M. Solignac, and J.-M. Cornuet. 1994. Precise assessment of the number of patrilines and of genetic relatedness in honey bee colonies. Proceedings of the Royal Society of London Series B-Biological Sciences 258:1-7.

Evans, J. D. 1998. Parentage and sex allocation in the facultatively polygynous ant Myrmica tahoensis. Behavioral Ecology and Sociobiology 44:35-42.

Fjerdingstad, E. J., P. J. Gertsch, and L. Keller. 2002. Why do some social insect queens mate with several males? Testing the sexratio manipulation hypothesis in Lasius niger. Evolution 56:553562.

-. 2003. The relationship between multiple mating by queens, within-colony genetic variability and fitness in the ant Lasius niger. Journal of Evolutionary Biology 16:844-853.

Foitzik, S. 1998. Population structure and sex allocation in the ant Leptothorax nylandera. Dissertation thesis, University of Würzburg, Würzburg.

Foitzik, S., and J. Heinze. 2001. Microgeographic genetic structure and intraspecific parasitism in the ant Leptothorax nylanderi. Ecological Entomology 26:449-456.

Foitzik, S., and J. M. Herbers. 2001. Colony structure of a slavemaking ant. I. Intracolony relatedness, worker reproduction, and polydomy. Evolution 55:307-315.

Foster, K. R., F. L. W. Ratnieks, and A. F. Raybould. 2000. Do hornets have zombie workers? Molecular Ecology 9:735-742.

Foster, R. L., A. Brunskill, D. Verdirame, and S. O'Donnell. 2004. Reproductive physiology, dominance interactions, and division of labour among bumble bee workers. Physiological Entomology 29:327-334.

Free, J. B. 1955. The behaviour of egg-laying workers of bumblebee colonies. British Journal of Animal Behaviour 3:147-153.

Free, J. B., and C. G. Butler. 1959. Bumblebees. Collins, London.

Gadau, J., J. Heinze, B. Hölldobler, and M. Schmid. 1996. Population and colony structure of the carpenter ant Camponotus floridanus. Molecular Ecology 5:785-792.

Goodisman, M. A. D., and D. A. Hahn. 2004. Colony genetic structure of the ant Camponotus ocreatus (Hymenoptera: Formicidae). Sociobiology 44:21-33.

Goodisman, M. A. D., R. W. Matthews, and R. H. Crozier. 2002. 
Mating and reproduction in the wasp Vespula germanica. Behavioral Ecology and Sociobiology 51:497-502.

Greeff, J. M. 1996. Effects of thelytokous worker reproduction on kin-selection and conflict in the Cape honeybee, Apis mellifera capensis. Philosophical Transactions of the Royal Society of London Series B-Biological Sciences 351:617-625.

Green, C. L., and B. P. Oldroyd. 2002. Queen mating frequency and maternity of males in the stingless bee Trigona carbonaria Smith. Insectes Sociaux 49:196-202.

Greene, A. 1979. Behavioural characters as indicators of yellowjacket phylogeny (Hymenoptera: Vespidae). Annals of the Entomological Society of America 72:614-619.

Greene, A., R. D. Akre, and P. Landolt. 1976. The aerial yellowjacket Dolichovespula arenaria (Fab.): nesting biology, reproductive production, and behaviour (Hymenoptera: Vespidae) Melanderia 26:1-34.

Halliday, R. B. 1983. Social organization of meat ants Iridomyrmex purpureus analysed by gel electrophoresis of enzymes. Insectes Sociaux 30:45-56.

Halling, L. A., and B. P. Oldroyd. 2003. Do policing honeybee (Apis mellifera) workers target eggs in drone comb? Insectes Sociaux 50:59-61.

Hammond, R., S. H. Cahan, and L. Keller. 2004. Control of worker reproduction in the multiply-mated ant Pogonomyrmex rugosus. Page 28 in Integrated Studies of Social Evolution - The Closing Symposium of the EU Research Training Network INSECTS, Lo-Skolen, Helsingoer, Denmark.

Hammond, R. L., M. W. Bruford, and A. F. G. Bourke. 2003. Male parentage does not vary with colony kin structure in a multiplequeen ant. Journal of Evolutionary Biology 16:446-455.

Hannonen, M., H. Helanterä, and L. Sundström. 2004. Habitat age, breeding system and kinship in the ant Formica fusca. Molecular Ecology 13:1579-1588.

Hartmann, A., P. D'Ettorre, G. R. Jones, and J. Heinze. 2005. Fertility signaling-the proximate mechanism of worker policing in a clonal ant. Naturwissenschaften 92:282-286.

Hasegawa, E. 1994. Sex allocation in the ant Colobopsis nipponicus (Wheeler). 1. Population sex ratio. Evolution 48:1121-1129.

Heinze, J. 1996. The reproductive potential of workers in slavemaking ants. Insectes Sociaux 43:319-328.

Heinze, J., and B. Hölldobler. 1995. Thelytokous parthenogenesis and dominance hierarchies in the ponerine ant, Platythyrea punctata. Naturwissenschaften 82:40-41.

Heinze, J., S. Foitzik, B. Oberstadt, O. Rüppell, and B. Hölldobler 1999. A female caste specialized for the production of unfertilized eggs in the ant Crematogaster smithi. Naturwissenschaften 86:93-95.

Heinze, J., M. Stratz, J. S. Pedersen, and M. Haberl. 2000. Microsatellite analysis suggests occasional worker reproduction in the monogynous ant Crematogaster smithi. Insectes Sociaux 47:299301.

Helanterä, H., and L. Sundström. 2005. Worker reproduction in the ant Formica fusca. Journal of Evolutionary Biology 18:162171.

Henshaw, M. T., J. E. Strassmann, S. Q. Quach, and D. C. Queller. 2000a. Male production in Parachartergus colobopterus, a neotropical, swarm-founding wasp. Ethology, Ecology \& Evolution 12:161-174.

Henshaw, M. T., J. E. Strassmann, and D. C. Queller. 2000b. The independent origin of a queen number bottleneck that promotes cooperation in the African swarm-founding wasp, Polybioides tabidus. Behavioral Ecology and Sociobiology 48:478-483.

Henshaw, M. T., D. C. Queller, and J. E. Strassmann. 2002. Control of male production in the swarm-founding wasp, Polybioides tabidus. Journal of Evolutionary Biology 15:262-268.

Herbers, J. M., and R. L. Mouser. 1998. Microsatellite DNA markers reveal details of social structure in forest ants. Molecular Ecology 7:299-306.

Hobbs, G. A. 1967. Ecology of species of Bombus (Hymenoptera: Apidae) in southern Alberta. VI. Subgenus Pyrobombus. Canadian Entomologist 99:1271-1292.

Hoffer, E. 1882-83. Die Hummeln Steiermarks. Lebensgeschichte und Beschreibung derselben. Leuschner \& Lubensky, Graz.

Iwanishi, S., and K. Ohkawara. 2005. The mechanism of the queen signal in regulation of worker reproduction in the myrmicine ant Aphaenogaster smythiesi japonica. Ethology Ecology \& Evolution 17:27-39.

Katayama, E. 1974. Egg-laying habits and brood development in Bombus hypocrita (Hymenoptera, Apidae). 1. Egg-laying habits of queens and workers. Kontyu 42:416-438.

-. 1997. Oviposition and oophagy by workers in queenright colonies of Bombus (Pyrobombus) ardens (Hymenoptera, Apidae). Japanese Journal of Entomology 65:23-35.

Katzav-Gozansky, T., V. Soroker, F. Ibarra, W. Francke, and A. Hefetz. 2001. Dufour's gland secretion of the queen honeybee (Apis mellifera): an egg discriminator pheromone or a queen signal? Behavioral Ecology and Sociobiology 51:76-86.

Kawabata, S., and K. Tsuji. 2005. The policing behavior 'immobilization' towards ovary-developed workers in the ant, Diacamma sp. from Japan. Insectes Sociaux 52:89-95.

Koedam, D., F. A. L. Contrera, and V. L. Imperatriz-Fonseca. 1999. Clustered male production by workers in the stingless bee Melipona subnitida Ducke (Apidae, Meliponinae). Insectes Sociaux 46:387-391.

Koedam, D., H. H. W. Velthuis, M. R. Dohmen, and V. L. Imperatriz-Fonseca. 2001. The behaviour of laying workers and the morphology and viability of their eggs in Melipona bicolor bicolor. Physiological Entomology 26:254-259.

Koedam, D., F. A. L. Contrera, A. D. Fidalgo, and V. L. ImperatrizFonseca. 2005. How queen and workers share in male production in the stingless bee Melipona subnitida Ducke (Apidae, Meliponini). Insectes Sociaux 52:114-121.

Kolmer, K., B. Hölldobler, and J. Heinze. 2002. Colony and population structure in Pachycondyla cf. inversa, a ponerine ant with primary polygyny. Ethology, Ecology \& Evolution 14:157-164.

Kronauer, D. J. C., C. Schöning, and J. J. Boomsma. 2006. Male parentage in army ants. Molecular Ecology 15: 1147-1151.

Kukuk, P., and B. May. 1991. Colony dynamics in a primitively eusocial halictine bee Lasioglossum (Dialictus) zephyrum (Hymenoptera: Halictidae). Insectes Sociaux 38:171-189.

Lindhard, E. 1912. Humelbien som Husdyr. Spredte Træk of nogle danske Humlebiarters Biologi. Tidsskr. Landbrugets Planteavl. 19:335-352.

Lopez-Vaamonde, C., J. W. Koning, R. M. Brown, W. C. Jordan, and A. F. G. Bourke. 2004. Social parasitism by male-producing reproductive workers in a eusocial insect. Nature 430:557-560.

Machado, M. F. P. S., E. P. B. Contel, and W. E. Kerr. 1984. Proportion of males sons-of-the-queen and sons-of-workers in Plebeia droryana (Hymenoptera, Apidae) estimated from data of an MDH isozymic polymorphic system. Genetica 65:193-198.

Martin, S. J., M. Beekman, T. C. Wossler, and F. L. W. Ratnieks. 2002a. Parasitic Cape honeybee workers, Apis mellifera capensis, evade policing. Nature 415:163-165.

Martin, S. J., G. R. Jones, N. Châline, H. Middleton, and F. L. W. Ratnieks. 2002b. Reassessing the role of the honeybee (Apis mellifera) Dufour's gland in egg marking. Naturwissenchaften 
89:528-532.

Martin, S. J., N. Châline, F. L. W. Ratnieks, and G. R. Jones. 2005. Searching for the egg-marking signal in honeybees. Journal of Negative Results 2:1-9.

Metcalf, R. A. 1980. Sex-ratios, parent-offspring conflict, and local competition for mates in the social wasps Polistes metricus and Polistes variatus. American Naturalist 116:642-654.

Miller, D. G., and F. L. W. Ratnieks. 2001. The timing of worker reproduction and breakdown of policing behaviour in queenless honey bee (Apis mellifera L.) societies. Insectes Sociaux 48:178184.

Miyano, S. 1983. Number of offspring and seasonal changes of their body weight in a paper wasp, Polistes chinensis antennalis Pérez (Hymenoptera, Vespidae), with reference to male production by workers. Researches on Population Ecology 25:198-209.

Mueller, U. G., G. C. Eickwort, and C. F. Aquadro. 1994. DNA fingerprinting analysis of parent-offspring conflict in a bee. Proceedings of the National Academy of Sciences of the USA 91:5143-5147.

Nakata, K. 1995. Age polyethism, idiosyncrasy and behavioral flexibility in the queenless ponerine ant, Diacamma sp. Journal of Ethology 13:113-123.

Nakata, K., and K. Tsuji. 1996. The effect of colony size on conflict over male-production between gamergate and dominant workers in the ponerine ant Diacamma sp. Ethology, Ecology \& Evolution 8:147-156.

Naumann, M. G. 1970. The nesting behavior of Protopolybia pumila (Saussure, 1863) (Hymenoptera: Vespidae) in Panama $\mathrm{PhD}$ thesis, University of Kansas, Kansas.

Neumann, P., C. W. W. Pirk, H. R. Hepburn, and R. F. A. Moritz. 2003. Spatial differences in worker policing facilitate social parasitism of Cape honeybee workers (Apis mellifera capensis Esch.) in queenright host colonies. Insectes Sociaux 50:109-112.

Owen, R. E., and R. C. Plowright. 1980. Abdominal pile color dimorphism in the bumble bee, Bombus melanopygus. Journal of Heredity 71:241-247.

Packer, L., and R. E. Owen. 1994. Relatedness and sex-ratio in a primitively eusocial halictine bee. Behavioral Ecology and Sociobiology 34:1-10.

Palmer, K. A., B. P. Oldroyd, E. J. J. G. Quezada, R. J. Paxton, and I. W. D. J. May. 2002. Paternity frequency and maternity of males in some stingless bee species. Molecular Ecology 11:21072113.

Pamilo, P. 1982. Multiple mating in Formica ants. Hereditas 97:3745.

Pamilo, P., and R. Rosengren. 1983. Sex ratio strategies in Formica ants. Oikos 40:24-35.

Paxton, R. J., H. Ruhnke, M. Shah, L. R. Bego, J. J. G. QuezadaEuan, and F. L. W. Ratnieks. 2001a. Social evolution in stingless bees: are the workers or is the queen in control of male production? Pages 104-17 in J. J. G. Quezada-Euan, ed. II Seminario Mexicano sobre abejas sin aguijón.

Paxton, R. J., P. A. Thoren, A. Estoup, and J. Tengo. 2001b. Queen-worker conflict over male production and the sex ratio in a facultatively polyandrous bumblebee, Bombus hypnorum: the consequences of nest usurpation. Molecular Ecology 10:24892498.

Paxton, R. J., L. R. Bego, M. M. Shah, and S. Mateus. 2003. Low mating frequency of queens in the stingless bee Scaptotrigona postica and worker maternity of males. Behavioral Ecology and Sociobiology 53:174-181.

Peters, J. M., D. C. Queller, V. L. Imperatriz-Fonseca, D. W. Roubik, and J. E. Strassmann. 1999. Mate number, kin selection and social conflicts in stingless bees and honeybees. Proceedings of the Royal Society of London Series B-Biological Sciences 266:379-384.

Plath, O. E. 1923. Notes on the egg-eating habits of bumblebees. Psyche 30:193-202.

Pomeroy, N. 1979. Brood bionomics of Bombus ruderatus in New Zealand (Hymenoptera: Apidae). Canadian Entomologist 111:865-874.

Queller, D. C., F. Zacchi, R. Cervo, S. Turillazzi, M. T. Henshaw, L. A. Santorelli, and J. E. Strassmann. 2000. Unrelated helpers in a social insect. Nature 405:784-787.

Ratnieks, F. L. W. 1993. Egg-laying, egg-removal, and ovary development by workers in queenright honey-bee colonies. Behavioral Ecology and Sociobiology 32:191-198.

-. 1995. Evidence for a queen-produced egg-marking pheromone and its use in worker policing in the honey-bee. Journal of Apicultural Research 34:31-37.

Richards, M. H., D. French, and R. J. Paxton. 2005. It's good to be queen: classically eusocial colony structure and low worker fitness in an obligately social sweat bee. Molecular Ecology 14:4123-4133.

Röseler, P. F., and C. G. J. van Honk. 1990. Castes and reproduction in bumblebees. Pages 147-166 in W. Engels, ed. Social Insects: An evolutionary approach to castes and development.

Ross, K. G. 1986. Kin selection and the problem of sperm utilization in social insects. Nature 323:798-800.

Rothenbuhler, W. C., J. M. Kulincevic, and W. E. Kerr. 1968. Bee genetics. Annual Review of Genetics 2:413-438.

Sanetra, M., and R. H. Crozier. 2001. Polyandry and colony genetic structure in the primitive ant Nothomyrmecia macrops. Journal of Evolutionary Biology 14:368-378.

Schilder, K., J. Heinze, R. Gross, and B. Hölldobler. 1999a. Microsatellites reveal clonal structure of populations of the thelytokous ant Platythyrea punctata (F. Smith) (Hymenoptera; Formicidae). Molecular Ecology 8:1497-1507.

Schilder, K., J. Heinze, and B. Hölldobler. 1999b. Colony structure and reproduction in the thelytokous parthenogenetic ant Platythyrea punctata (F. Smith) (Hymenoptera, Formicidae). Insectes Sociaux 46:150-158.

Schmid-Hempel, R., and P. Schmid-Hempel. 2000. Female mating frequencies in Bombus spp. from Central Europe. Insectes Sociaux 47:36-41.

Simões, D. 1977. Etologia e diferenciação de casta em algumas vespas sociais (Hymenoptera, Vespidae). PhD thesis, Ribeirão Preto- USP.

Sladen, F. W. L. 1912. The Humble-bee, its Life-History and how to Domesticate it. Macmillan \& Co, London.

Sommeijer, M. J., J. L. Houtekamer, and W. Bos. 1984. Cell construction and egg-laying in Trigona nigra paupera with a note on the adaptive significance of oviposition behavior of stingless bees. Insectes Sociaux 31:199-217.

Sommeijer, M. J., T. X. Chinh, and F. J. A. J. Meeuwsen. 1999. Behavioural data on the production of males by workers in the stingless bee Melipona favosa (Apidae, Meliponinae). Insectes Sociaux 46:92-93.

Strassmann, J. E. 2001. The rarity of multiple mating by females in the social hymenoptera. Insectes Sociaux 48:1-13.

Suzuki, T. 1986. Production schedules of males and reproductive females, investment sex-ratios, and worker-queen conflict in paper wasps. American Naturalist 128:366-378.

Takahashi, J., S. Akimoto, E. Hasegawa, and J. Nakamura. 2002. Queen mating frequencies and genetic relatedness between workers in the hornet Vespa ducalis (Hymenoptera: Vespidae). 
Applied Entomology and Zoology 37:481-486.

Takahashi, J., S. Akimoto, S. J. Martin, M. Tamukae, and E. Hasegawa. 2004a. Mating structure and male production in the giant hornet Vespa mandarinia (Hymenoptera: Vespidae). Applied Entomology and Zoology 39:343-349.

Takahashi, J., J. Nakamura, S. Akimoto, and E. Hasegawa. 2004b. Kin structure and colony male reproduction in the hornet Vespa crabro (Hymenoptera: Vespidae). Journal of Ethology 22:43-47.

Tóth, E., D. C. Queller, V. L. Imperatriz-Fonseca, and J. E. Strassmann. 2002a. Genetic and behavioral conflict over male production between queens and workers in the stingless bee Paratrigona subnuda. Behavioral Ecology and Sociobiology 53:1-8.

Tóth, E., J. E. Strassmann, V. L. Imperatriz-Fonseca, and D. C. Queller. 2003. Queens, not workers, produce the males in the stingless bee Schwarziana quadripunctata quadripunctata. Animal Behaviour 66:359-368.

Tsuchida, K., T. Saigo, N. Nagata, S. Tsujita, K. Takeuchi, and S. Miyano. 2003. Queen-worker conflicts over male production and sex allocation in a primitively eusocial wasp. Evolution 57:2365-2373.

van der Have, T. M., J. J. Boomsma, and S. B. J. Menken. 1988. Sex investment ratios and relatedness in the monogynous ant Lasius niger (L.). Evolution 42:160-172.

Van Doorn, A. 1987. Investigations into the regulation of dominance behaviour and of the division of labour in bumblebee colonies (Bombus terrestris). Netherlands Journal of Zoology 37:255-276. van Honk, C., and P. Hogeweg. 1981. The ontogeny of the social structure in a captive Bombus terrestris colony. Behavioral Ecology and Sociobiology 9:111-119.

van Honk, C. G. J., P. F. Röseler, H. H. W. Velthuis, and J. C. Hoogeveen. 1981. Factors influencing the egg laying of workers in a captive Bombus terrestris colony. Behavioral Ecology and Sociobiology 9:9-14.

Villesen, P., and J. J. Boomsma. 2003. Patterns of male parentage in the fungus-growing ants. Behavioral Ecology and Sociobiology 53:246-253.

Villesen, P., P. J. Gertsch, J. Frydenberg, U. G. Mueller, and J. J. Boomsma. 1999. Evolutionary transition from single to multiple mating in fungus-growing ants. Molecular Ecology 8:1819-1825.

Visscher, P. K. 1989. A quantitative study of worker reproduction in honeybee colonies. Behavioral Ecology and Sociobiology 25:247-254.

-. 1996. Reproductive conflict in honey bees: a stalemate of worker egg-laying and policing. Behavioral Ecology and Sociobiology 39:237-244.

Ward, P. S. 1983. Genetic relatedness and colony organization in a species complex of ponerine ants I. Phenotypic and genotypic composition of colonies. Behavioral Ecology and Sociobiology 12:285-299.

Wattanachaiyingcharoen, W., B. P. Oldroyd, G. Good, L. Halling, F. L. W. Ratnieks, and S. Wongsiri. 2002. Lack of worker reproduction in the giant honey bee Apis dorsata Fabricius. Insectes Sociaux 49:80-85. 